\title{
Uma contribuição à geografia dos recursos hídricos
}

\author{
Eugênio Antônio de Lima \\ Hellen Cano \\ José Antônio Sena do Nascimento
}

A água constitui elemento essencial à vida, enquanto componente biológico dos seres vivos e meio de vida de várias espécies vegetais e animais, assim como fator fundamental de localização dos assentamentos humanos e, portanto, de entendimento das formas de organização socioeconômica do Território Nacional.

A divisão do território brasileiro segundo a distribuição espacial dos recursos hídricos longe de constituir uma simples e tradicional delimitação geográfica do País adquire, na atualidade, uma importância central para a gestão do Território Nacional notadamente quando se considera o sentido estratégico que vem adquirindo a regulação do uso dos recursos hídricos.

Com efeito, nenhum outro recurso natural oferece tantos usos socioeconômicos quanto a água, incluindo seu aproveitamento para o abastecimento doméstico e industrial e como matéria-prima nas atividades industriais e agrícolas, para geração de energia e irrigação, entre outros. Este capítulo tem, assim, como objetivo delinear algumas diferenças geográficas relacionadas com uso e a disponibilidade dos recursos hídricos no Brasil.

A água é vista aqui, contudo, não somente como um recurso, mas como um serviço ${ }^{1}$ prestado pelos ecossistemas ao bem-estar humano, bem como ela é considerada um sistema em si constituído de águas interiores.

\footnotetext{
1 Serviços ecossistêmicos são os benefícios que as pessoas adquirem dos ecossistemas saudáveis, os quais são descritos pela Avaliação Ecossistêmica do Milênio como serviços de produção, de regulação, de suporte, e culturais (ECOSYSTEMS..., 2003). Os serviços de produção ou aprovisionamento são os bens que se obtém dos ecossistemas tais como alimento, combustível, fibras, água potável, e recursos genéticos. Os serviços de regulação são os benefícios que se obtém da regulação de processos dos ecossistemas, inclusive a manutenção da qualidade do ar, regulação do clima, controle da erosão, regulação de doenças humanas e purificação da água. Os serviços culturais são os benefícios não materiais que as pessoas obtêm dos ecossistemas através de enriquecimento espiritual, desenvolvimento cognitivo, e experiências de reflexão, de recreação e estéticas. Serviços de suporte são aqueles que são necessários para a produção de todos os outros serviços de ecossistemas, como a produção primária, a produção de oxigênio, e a formação de solo. Mudanças na integridade dos ecossistemas e na biodiversidade afetam esses serviços e podem impactar o bem-estar humano de várias formas.
} 
Como o ciclo da água desempenha muitos papéis no clima, na química e na biologia da Terra, é difícil defini-lo distintamente como um serviço de suporte, de regulação ou de provisionamento. A precipitação, que cai como chuva ou neve, é a melhor fonte de água para os ecossistemas. Os ecossistemas, por sua vez, controlam o caráter de renovação do recurso água doce para o bem-estar humano [...] Juntamente com a energia e os nutrientes, a água é, sem dúvida, a peça central para a prestação de serviços ecossistêmicos para a humanidade. (FALKENMARK; FOLKE, 2003 apud ECOSYSTEMS..., 2005, p. 168, tradução nossa)

Embora o papel de todos os serviços ecossistêmicos da água sejam importantes, o mais bem documentado é o serviço de provisionamento, em parte porque os recursos hídricos são o bem mais tangível, mais facilmente mensurável, diferentemente da mensuração dos demais, como o serviço de regulação das vazões dos rios, do papel da água no ciclo hidrológico e na manutenção de florestas, dentre outros.

O presente capítulo concentra-se na análise de um tema central ao avanço do conhecimento dos recursos hídricos no Brasil que é aquele relativo a sua distribuição geográfica no Território Nacional.

Para tanto, ele reúne informações demográficas, econômicas e ambientais que caracterizam não só a geografia das águas superficiais - as regiões hidrográficas - como a das águas subterrâneas - as províncias hidrogeológicas - possibilitando, portanto, uma visão inicial de duas vertentes fundamentais e complementares que envolvem a problemática em torno da distribuição desigual dos recursos hídricos no imenso território brasileiro.

Esse capítulo constitui, portanto, uma contribuição inicial na elaboração, em escala nacional, de um grande quadro de referência sobre questões conceituais, metodológicas e operacionais recorrentes na discussão em torno da inserção dos recursos hídricos no planejamento territorial do Brasil.

Nesse sentido, na parte referente às águas superficiais, ele reúne um conjunto de informações que permitem fazer uma leitura regionalizada dos recursos hídricos no País, com destaque para o cruzamento de informações básicas derivadas da dimensão socioeconômica, tais como o tamanho e densidade da população e o Produto Interno Bruto - PIB municipal, além daquelas oriundas do quadro natural, associadas aos biomas brasileiros.

Na parte referente às águas subterrâneas, o capítulo descreve a conjugação de fatores geológicos, geomorfológicos e climáticos que servem como parâmetro para definir as regiões denominadas de províncias hidrogeológicas, nos quais os sistemas aquíferos apresentam condições hidrogeológicas semelhantes no que se refere ao armazenamento, circulação, descarga e qualidade química das águas.

Um foco especial é dado à Região Nordeste, possibilitando um conhecimento mais detalhado da geografia das águas subterrâneas dessa imensa e importante região do País, cuja deficiência hídrica constitui histórico condicionante e renovado desafio no que diz respeito às formas social e ambientalmente sustentáveis de apropriação e uso de seu território.

Finalmente, o tema da vulnerabilidade social e ambiental conclui o presente capítulo apontando para questões centrais que envolvem a importância estratégica que a informação sobre o acesso e a qualidade dos recursos hídricos possui no avanço da quantificação estatística e da análise geográfica acerca da qualidade de vida da população em um momento histórico que passa por um acelerado processo de alterações climáticas. 


\section{Regiões hidrográficas: fundamentação e operacionalização de um recorte espacial}

Dada as dimensões continentais do Brasil e a grande diversidade de condições de disponibilidade de água, bem como de atendimento das necessidades básicas da população relacionadas com os recursos hídricos, como é o caso do saneamento, a escolha de recortes espaciais relevantes para o estudo de realidades específicas ao tema representou um marco inicial para a caracterização pretendida dos recursos hídricos em escala nacional.

Nesse contexto, pode-se afirmar que a divisão de bacias hidrográficas de um determinado país representa um desafio e sua compartimentação depende dos objetivos que se pretende atingir, da concepção metodológica adotada e, sobretudo, da escala de apresentação.

Desta forma, concluiu-se que a região hidrográfica, unidade geográfica reconhecidamente utilizada para o planejamento dos recursos hídricos, seria o recorte espacial de nível de agregação compatível com as dimensões dos biomas, contextos econômicos regionais e macro vetores da expansão populacional do País.

O Sistema Nacional de Gerenciamento de Recursos Hídricos pode ser considerado a representação concreta da Política Nacional de Recursos Hídricos instituída pela Lei n. 9.433 de 08.01.1997, com o objetivo principal de prevenção e uso racional das águas, além da proposição de criação dos comitês de bacias hidrográficas. Desde esta data reconhece-se a bacia hidrográfica ${ }^{2}$ como a unidade de planejamento para as questões relacionadas com a água.

Havia, entretanto, a necessidade de um novo conceito para operacionalizar a Política Nacional dos Recursos Hídricos e o Sistema Nacional de Gerenciamento de Recursos Hídricos. Assim, em 2003, o Conselho Nacional de Recursos Hídricos - CNRH regulamentou e institucionalizou a região hidrográfica como unidade do gerenciamento de recursos hídricos com o objetivo de orientar, fundamentar e implementar o Plano Nacional de Recursos Hídricos.

Nesse contexto, a Resolução n. 32, de 15.10.2003 do CNRH, considerou como região hidrográfica "o espaço territorial brasileiro compreendido por uma bacia, grupo de bacias ou subbacias hidrográficas contíguas com características naturais, sociais e econômicas homogêneas ou similares, com vistas a orientar o planejamento e gerenciamento dos recursos hídricos".

No que se refere especificamente ao tema dos recursos hídricos, a utilização de uma base de informações atualizada e disponível sobre as características da população, fatores de pressão referentes às condições de vida e às atividades econômicas permite uma análise abrangente e mais completa para avaliação da disponibilidade hídrica e questões relacionadas com o recorte espacial escolhido, no caso, as regiões hidrográficas (Mapa 1), cuja caracterização a seguir é baseada nos dados do relatório Conjuntura dos recursos hídricos no Brasil 2013, publicado pela Agência Nacional de Águas - ANA.

\footnotetext{
2 De modo geral, os limites das bacias são definidos de acordo com critérios técnicos que incluem a separação dos divisores de água a partir da identificação das cabeceiras dos canais de primeira ordem, chegando-se à delimitação dos rios que formam a rede de drenagem principal. Assim, dependendo da escala do mapa a divisão hidrográfica pode ser cada vez mais detalhada e, portanto, comportar inúmeras subdivisões. Segundo a classificação de Otto Pfasfstetter, o Brasil possui seis bacias de ordem 1; 39 bacias de ordem 2; 351 bacias de ordem 3; 2541 bacias de ordem 4; 14921 bacias de ordem 5; e 60001 bacias de ordem 6 (CONJUNTURA..., 2013).
} 
Mapa 1 - Regiões hidrográficas

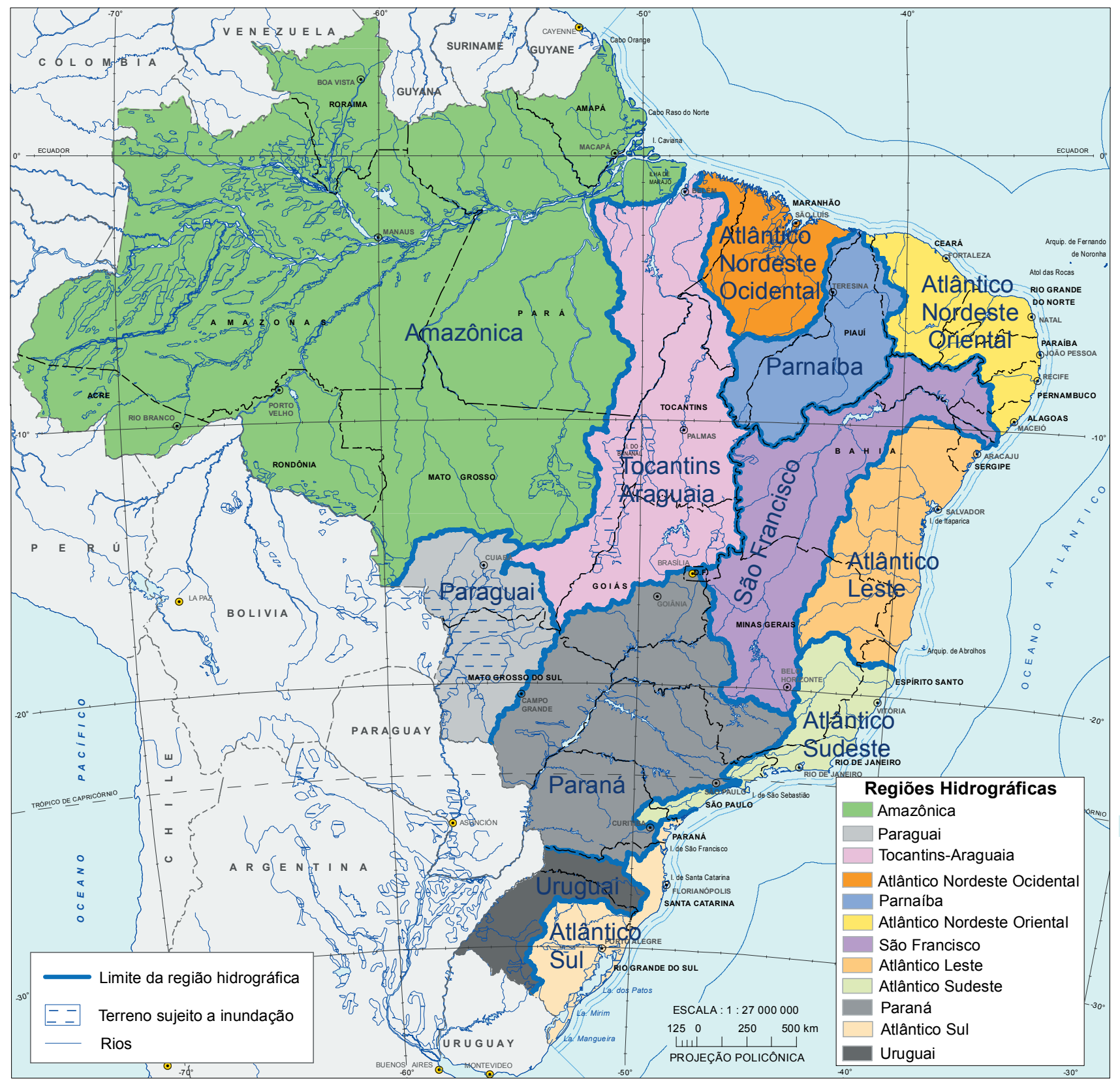

Fonte: Conselho Nacional de Recursos Hídricos (Brasil). Resolução n. 32, de 15 de outubro de 2003. Brasília, DF, 2003. Extraído de: Atlas Nacional do Brasil Milton Santos. Rio de Janeiro: IBGE, 2010. Disponível em: <http://biblioteca.ibge.gov.br/index.php/biblioteca-catalogo? view=detalhes\&id=247603>. Acesso em jun. 2016. 


\section{Distribuição da população nas regiões hidrográficas}

Nos aspectos populacionais, a distribuição da população pelas regiões hidrográficas revela um padrão concentrado onde se destaca a Região Hidrográfica do Paraná como a mais populosa, em contraste com a Região Hidrográfica Paraguai, a menos populosa. O Mapa 2 e a Tabela 1 apresentam a distribuição populacional segundo as 12 regiões hidrográficas do Brasil.

O exame da distribuição populacional por região hidrográfica da forma mais agregada, como apresentada no Mapa 2, é útil no sentido de explicar parte da pressão que a população exerce sobre os recursos hídricos, principalmente no que se refere ao consumo das famílias (abastecimento de água e saneamento). Outros tipos de uso da água, como irrigação e consumo industrial não estão diretamente ligados ao consumo da população local, pois, muitas vezes, cultivos agrícolas para exportação e produtos da indústria são enviados para fora da região hidrográfica.

Situações de escassez de água, como a vivenciada de forma generalizada em várias regiões hidrográficas do Brasil em 2014, demonstram a necessidade de revisão de políticas públicas que regulam o uso intensivo da água na produção econômica sem levar em conta os limites dos recursos hídricos, bem como revelam a urgência de programas e campanhas de conscientização do uso racional da água pela população e pelos demais setores usuários.

A geografia da densidade populacional por setores censitários (Mapa 3) revela que a distribuição populacional interna a cada região hidrográfica possui aspectos distintos, com áreas de alta concentração demográfica, em geral referentes às capitais estaduais e grandes cidades, em oposição a índices baixíssimos em extensas áreas do País.

No Mapa 3 ficam evidenciadas as marcadas diferenças que coexistem no interior das regiões hidrográficas. Nesse sentido, individualmente, elas podem possuir adensamentos populacionais distribuídos distintamente no território, variando de menos de 1 habitante por quilômetro quadrado $\left(\mathrm{hab} / \mathrm{km}^{2}\right)$ até mais de $500 \mathrm{hab} / \mathrm{km}^{2}$. Observam-se também adensamentos de até $100 \mathrm{hab} / \mathrm{km}^{2}$ em regiões hidrográficas esparsamente habitadas, como é o caso da Amazônia (2,7 hab/km²-por região hidrográfica), e vazios demográficos nas Regiões Hidrográficas do Paraná e do Atlântico Sudeste, por exemplo, pertencentes a classes de altas densidades demográficas (Mapa 2 e Tabela 1).

As desigualdades observadas na distribuição das densidades demográficas entre as regiões hidrográficas (Tabela 1) e no interior das regiões hidrográficas (Mapa 3) reafirmam a necessidade de se caminhar no sentido da visão integrada e multiescalar que permita interligar as formas de uso dos recursos hídricos às igualmente diferenciadas formas de povoamento engendradas pela sociedade ao longo do tempo, aí incluídos, os processos de urbanização e de formação de manchas crescentes de alta concentração da população no espaço geográfico. 
Mapa 2 - Densidade demográfica e população total nas regiões hidrográficas - 2013

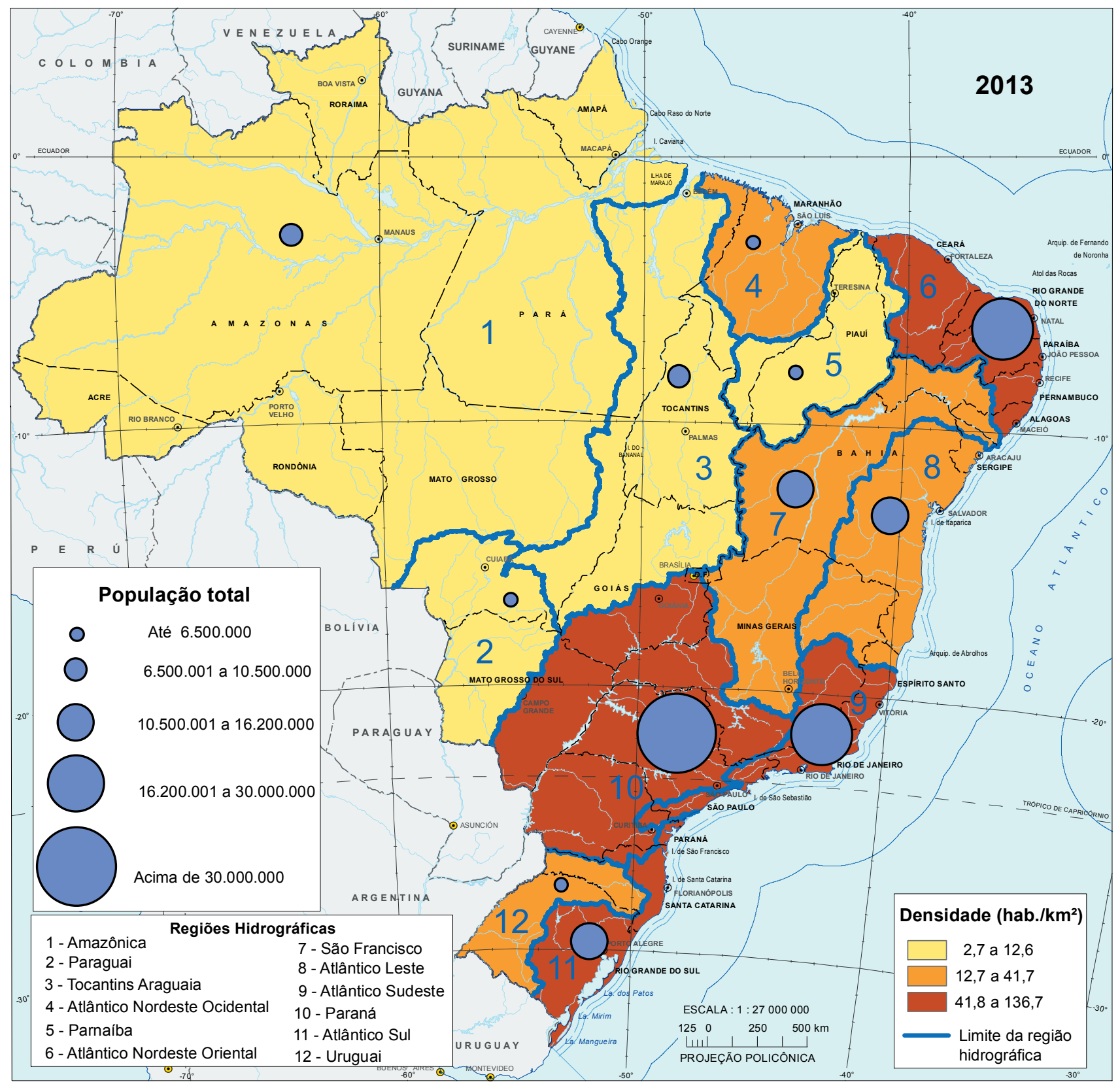

Fontes: 1. Estimativas da população residente nos municípios brasileiros com data de referência em 1o de julho de 2013. Rio de Janeiro: IBGE, 2013. Disponível em: <ftp://ftp.ibge.gov.br/Estimativas_de_Populacao>. Acesso em: maio 2016. 2. Conselho Nacional de Recursos Hídricos (Brasil). Resolução n. 32 , de 15 de outubro de 2003. Brasília, DF, 2003. Disponível em: <http://www.cnrh.gov.br/index.php?option=com_content\&view=article\&id=14>. Acesso em: maio 2016. 
Mapa 3 - Regiões hidrográficas e distribuição da população - 2013

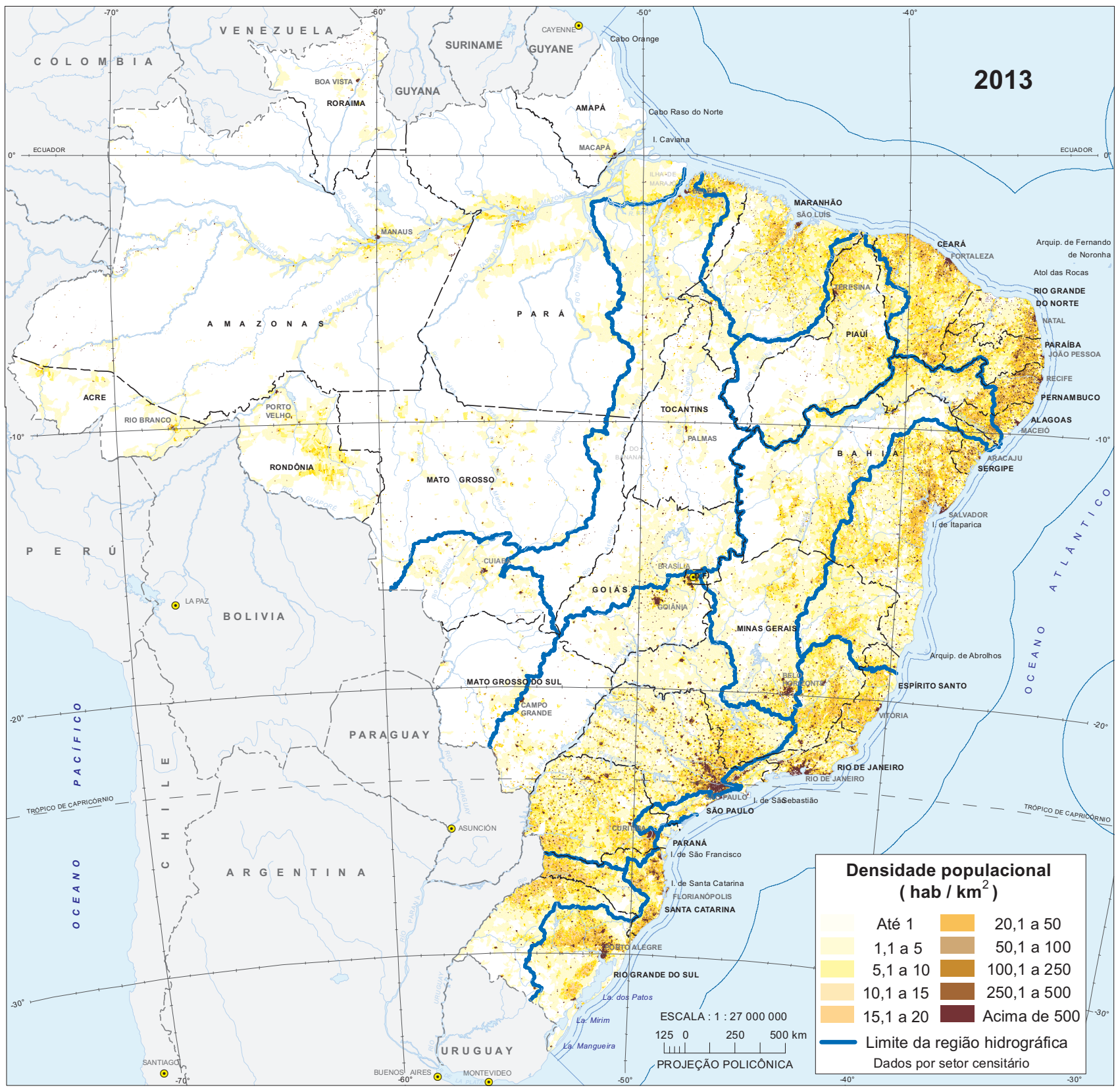

Fontes: 1. Estimativas da população residente nos municípios brasileiros com data de referência em 1o de julho de 2013. Rio de Janeiro: IBGE, 2013. Disponível em: <ftp://ftp.ibge.gov.br/Estimativas_de_Populacao>. Acesso em: maio 2016. 2. Conselho Nacional de Recursos Hídricos (Brasil). Resolução n. 32, de 15 de outubro de 2003. Brasília, DF, 2003. Disponível em: <http://www.cnrh.gov.br/index.php?option=com_content\&view=article\&id=14>. Acesso em: maio 2016. 
Tabela 1 - Área, distribuição da população e densidade nas regiões hidrográficas - 2013

\begin{tabular}{rlr|r|r}
\hline \multicolumn{1}{c|}{ Região hidrográfica } & Área $\left(\mathrm{km}^{2}\right)$ & População & Densidade $\left(\mathrm{hab} / \mathrm{km}^{2}\right)$ \\
\hline 1 Amazônia & 3869953 & 10458790 & 2,7 \\
2 Paraguai & 363446 & 3111356 & 8,6 \\
3 & Tocantins-Araguaia & 918822 & 8992847 & 9,8 \\
4 & Atlântico Nordeste Ocidental & 274301 & 6393828 & 23,3 \\
5 & Parnaíba & 333056 & 4209040 & 12,6 \\
6 & Atlântico Nordeste Oriental & 286802 & 25278051 & 88,1 \\
7 & São Francisco & 638576 & 15015855 & 23,5 \\
8 & Atlântico Leste & 388160 & 16174377 & 41,7 \\
9 & Atlântico Sudeste & 214629 & 29339937 & 136,7 \\
10 & Paraná & 879873 & 64322182 & 73,1 \\
11 & Atlântico Sul & 187522 & 13574899 & 72,4 \\
12 & Uruguai & 174533 & 4136331 & 23,7 \\
\hline
\end{tabular}

Fontes: 1. Estimativas da população residente nos municípios brasileiros com data de referência em 1 de julho de 2013 . Rio de Janeiro: IBGE, 2013. Disponível em: <ftp://ftp.ibge.gov.br/Estimativas_de_Populacao>. Acesso em: maio 2016. 2. Conjuntura dos recursos hídricos no Brasil 2013. Brasília, DF: Agência Nacional de Águas - ANA, 2013. Disponível em: <http:// arquivos.ana.gov.br/institucional/spr/conjuntura/webSite_relatorioConjuntura/projeto/index.html>. Acesso em: maio 2016.

\section{Distribuição das atividades econômicas e regiões hidrográficas}

Ao lado dos fatores de pressão diretamente relacionados ao consumo de água pela população, a pressão exercida pelas atividades econômicas deve ser analisada no contexto da gestão dos recursos hídricos. Como destacado anteriormente, muitas vezes a utilização da água em determinadas bacias e regiões hidrográficas pode estar diretamente relacionada ao tipo de uso da terra e fatores de produção do que ao consumo direto da população que nela vive.

O PIB dos Municípios, calculado pelo IBGE para todos os municípios brasileiros, é reflexo e produto, de certa forma, da grande diversidade do capital natural, assim como das variações climáticas e contextos econômicos, sociais e políticos diferenciados que interagem nas 5565 unidades administrativas municipais no ano de 2011.

A Tabela 2 e o Mapa 4 apresentam os totais aproximados do PIB dos Municípios por região hidrográfica. Nestes, observa-se as diferenças espaciais na concentração do PIB e, por conseguinte, na distribuição das atividades econômicas entre as regiões hidrográficas. 
Tabela 2 - Produto Interno Bruto aproximado, total e per capita, segundo as regiões hidrográficas - 2011

\begin{tabular}{|c|c|c|c|}
\hline \multirow{2}{*}{\multicolumn{2}{|c|}{ Região hidrográfica }} & \multicolumn{2}{|c|}{ PIB aproximado } \\
\hline & & Total (1 $000 \mathrm{R} \$$ ) & Per capita ( $\mathrm{R} \$)$ \\
\hline 1 & Amazônia & 139400000 & 13329 \\
\hline 2 & Paraguai & 50200000 & 16134 \\
\hline 3 & Tocantins-Araguaia & 288300000 & 32059 \\
\hline 4 & Atlântico Nordeste Ocidental & 36000000 & 5630 \\
\hline 5 & Parnaíba & 28100000 & 6676 \\
\hline 6 & Atlântico Nordeste Oriental & 250700000 & 9918 \\
\hline 7 & São Francisco & 202000000 & 13452 \\
\hline 8 & Atlântico Leste & 178700000 & 11048 \\
\hline 9 & Atlântico Sudeste & 593200000 & 20218 \\
\hline 10 & Paraná & 1617000000 & 25139 \\
\hline 11 & Atlântico Sul & 323000000 & 23794 \\
\hline 12 & Uruguai & 62300000 & 15062 \\
\hline
\end{tabular}

Fontes: 1. IBGE, Produto Interno Bruto dos Municípios 2012. 2. Conjuntura dos recursos hídricos no Brasil 2013. Brasília, DF: Agência Nacional de Águas - ANA, 2013. Disponível em <http://arquivos.ana.gov.br/institucional/spr/conjuntura/webSite_ relatorioConjuntura/projeto/index.html>. Acesso em: maio 2016.

Apesar de manter padrão similar ao da concentração populacional, o Mapa 4 revela aspectos diferenciados das formas de apropriação e uso do território brasileiro e, portanto, da distribuição das atividades econômicas no País. É o caso, por exemplo, da Região Hidrográfica do Tocantins-Araguaia que, em virtude de sua produção agropecuária e da presença da capital federal, situa-se, em termos de PIB total, em patamar semelhante a outras regiões hidrográficas bem mais populosas.

No campo das estatísticas ambientais existem na atualidade estratégias internacionais que visam quantificar, em termos físicos e monetários, a relação entre o uso da água nos setores econômicos (indústria, agropecuária e saneamento) ${ }^{3}$ e as reservas existentes, para aferir com maior precisão o real valor desse recurso natural.

Nesse sentido, o reconhecimento das diferenças regionais constitui um elemento central no caminho da incorporação das especificidades econômicas e ambientais, essenciais para relacionar o uso dos recursos hídricos e a capacidade das reservas de água em face dos múltiplos usos que as atividades humanas pressupõem.

\footnotetext{
3 Destacam-se os seguintes documentos: International recommendations for water statistics (2012); o System of environmental-economic accounting 2012: central framework (2014); e o System of environmental-economic accounting for water - SEEA-water (2012) elaborados pela mesma organização e adotados como padrão internacional pela Comissão de Estatísticas das Nações Unidas (United Nations Statistical Commission - UNSC).
} 
Mapa 4 - Produto Interno Bruto nas regiões hidrográficas - 2010

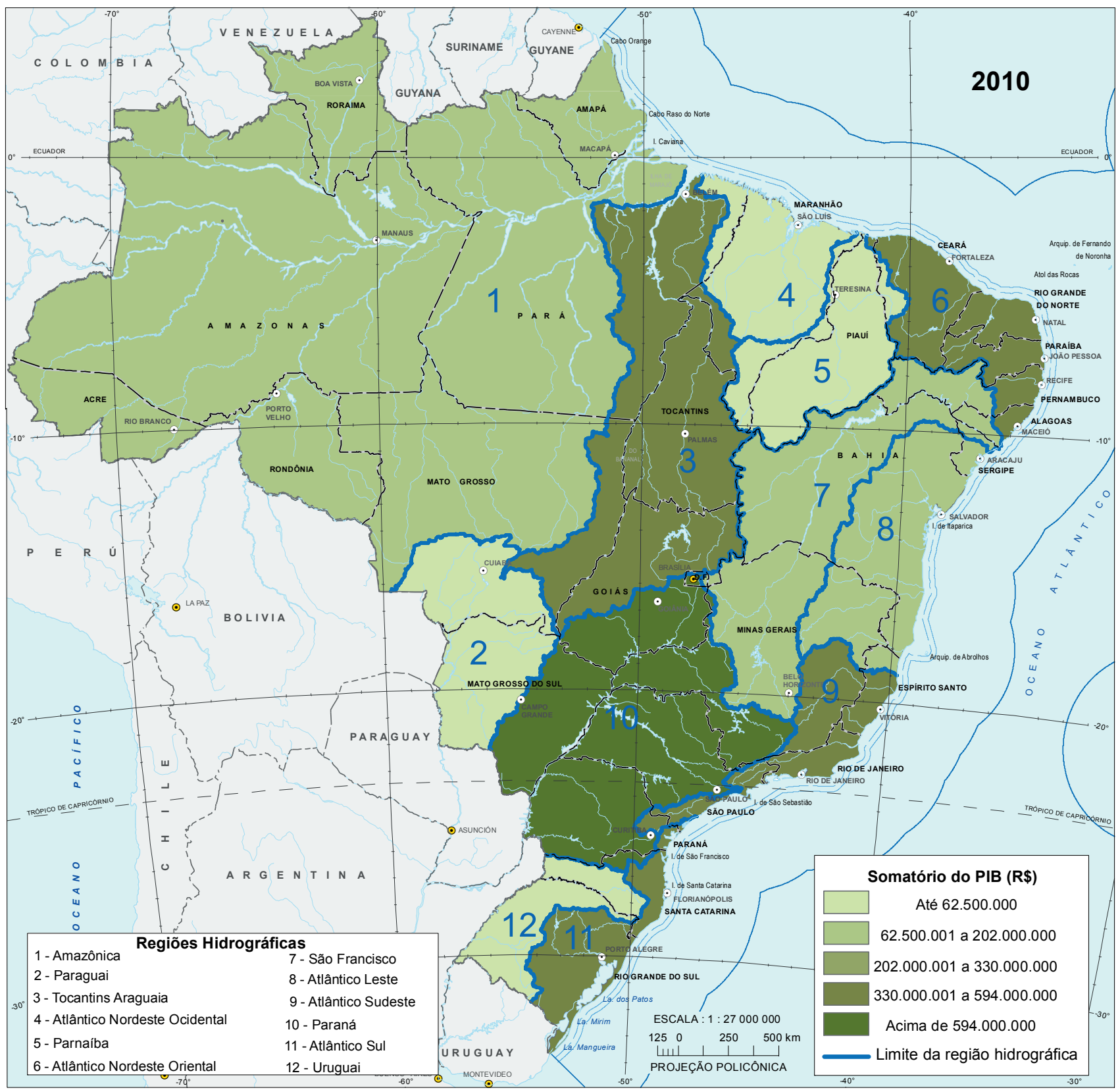

Fontes: 1. IBGE, Produto Interno Bruto dos Municípios 2012. 2. Conselho Nacional de Recursos Hídricos (Brasil). Resolução n. 32 , de 15 de outubro de 2003. Brasília, DF, 2003. Disponível em: <http://www.cnrh.gov.br/index.php?option=com_content\&view=article\&id=14>. Acesso em: maio 2016 


\section{Caracterização socioeconômica das regiões hidrográficas brasileiras}

Uma contextualização inicial das regiões hidrográficas brasileiras constitui etapa obrigatória para se avançar no processo de quantificação/valoração dos recursos hídricos em escala regional. Assim, reunimos aqui informações relevantes na caracterização das formas dominantes de uso dos recursos hídricos em cada uma das regiões.

\section{Região Hidrográfica Amazônica}

A Região Hidrográfica Amazônica é constituída pela Bacia Hidrográfica do Rio Amazonas em Território Nacional, pelas bacias hidrográficas dos rios existentes na Ilha de Marajó, além das bacias hidrográficas dos rios situados no Estado do Amapá que deságuam no Atlântico Norte, de acordo com a Resolução n. 32, de 15.10.2003 do CNRH, perfazendo um total de $3869953 \mathrm{~km}^{2}$.

A população na Região Hidrográfica Amazônica, em 2013, era de 10458790 habitantes (5,2\% da população do País) e a densidade demográfica de apenas 2,7 hab/km², enquanto sua área ocupa 42,0\% do Território Nacional.

As capitais estaduais de Manaus, Rio Branco, Porto Velho, Boa Vista e Macapá, bem como os Municípios de Santarém (PA) e Sinop (MT), são os centros urbanos que mais se destacam dentre os 304 municípios da Região Hidrográfica Amazônica.

Segundo a Agência Nacional de Águas - ANA, a Bacia Hidrográfica do Rio Amazonas é constituída pela mais extensa rede hidrográfica do globo terrestre, ocupando uma área total da ordem de $6110000 \mathrm{~km}^{2}$, desde suas nascentes na região dos Andes peruanos até sua foz no Oceano Atlântico (na Região Norte do Brasil) (CONJUNTURA..., 2013). Esta bacia continental se estende por vários países da América do Sul: Brasil $(63,0 \%)$, Peru $(17,0 \%)$, Bolívia (11,0\%), Colômbia (5,8\%), Equador (2,2\%), Venezuela $(0,7 \%)$ e Guiana $(0,2 \%)$.

Em termos de vazão, a contribuição média da Bacia Hidrográfica do Rio Amazonas, em território brasileiro, é da ordem de 132145 metros cúbicos por segundo (m³/s) (73,6\% do total do País). Adicionalmente, a contribuição de territórios estrangeiros para as vazões da região hidrográfica é da ordem de 76000 m³/s.

As maiores demandas pelo uso da água na região ocorrem nas sub-bacias dos Rios Tapajós, Madeira e Negro, e tem por finalidade o uso para abastecimento humano e dessedentação animal, representando, respectivamente, $33,0 \%$ e $32,0 \%$ da demanda total da região, que é de 78,8 m³/s. De modo geral, os consumos estimados são pouco significativos quando comparados com a disponibilidade hídrica por sub-bacia (CONJUNTURA..., 2013).

\section{Região Hidrográfica do Paraguai}

A Região Hidrográfica do Paraguai inclui uma das maiores extensões úmidas contínuas do planeta, o Pantanal, considerado patrimônio nacional, pela Constituição Federal do Brasil, de 1988, e Reserva da Biosfera, pela Organização das Nações Unidas para a Educação, a Ciência e a Cultura (United Nations Educational Scientific and Cultural Organization UNESCO), no ano 2000. 
As áreas úmidas são ecossistemas na interface entre ambientes aquáticos e terrestres; elas podem ser continentais ou litorâneas, naturais ou artificiais, permanentes ou periodicamente inundadas por águas rasas ou consistem em solo encharcado. Suas águas podem ser frescas, ou muito ou moderadamente salinas. As zonas úmidas são o lar de comunidades vegetais e animais específicos, adaptados às sua dinâmica hidrológica. (JUNK et al., 2014, p. 12, tradução nossa).

Essas áreas fornecem habitats que são de fundamental relevância para a manutenção da integridade funcional e da biodiversidade. A importância desta região hidrográfica deve-se, em parte, ao que assegura a Avaliação Ecossistêmica do Milênio:

Áreas úmidas oferecem diversos serviços para a sociedade, tais como o armazenamento de água, o tamponamento do rio e descarga de córregos, recarga de águas subterrâneas, retenção de sedimentos, purificação de água, a regulação do microclima, recreação e ecoturismo, armazenamento de carbono, a produção de madeira, e da provisão de produtos não-madeireiros, plantas medicinais, peixe, produtos agrícolas, água potável para seres humanos e animais, e terras para criação de animais. Além disso, contribuem para a preservação cultural, fornecendo abrigo e condições de vida para comunidades tradicionais (ECOSYSTEMS..., 2005 apud JUNK et al., 2014, p. 6, tradução nossa).

O principal rio dessa região hidrográfica é o Paraguai, que nasce em território brasileiro e drena uma área de 1095000 km²: 33,0\% no Brasil (363446 km²) e o restante na Argentina, Bolívia e Paraguai.

Cerca de 3111356 pessoas residiam na região em 2013, o equivalente a 1,54\% da população do Brasil nesse ano, sendo 87,0\% em áreas urbanas (ESTIMATIVAS..., 2013). Os Municípios de Cuiabá (MT) com 551 mil habitantes, Várzea Grande (MT) com 253 mil, Rondonópolis (MT) com 195 mil, Corumbá (MS) com 104 mil e Cáceres (MT) com 88 mil habitantes, representam os principais centros populacionais.

Na Região Hidrográfica do Paraguai estão presentes, além do Pantanal, o Bioma Cerrado e zonas de transição entre os dois biomas. Os tipos de vegetação predominantes são as Savanas Arborizada (Cerrado) e Florestada (Cerradão).

Com relação aos indicadores de saneamento básico do Censo Demográfico 2010, 93,0\% dos habitantes dessa região tinham acesso à rede de abastecimento de água, percentual semelhante ao valor médio nacional que é de 91,0\%. Por outro lado, a rede de esgoto alcançava apenas 29,0\% da população, muito abaixo, portanto, da média nacional. Quanto ao esgoto tratado, a região apresentava um percentual de 19,0\%, abaixo da média nacional de 30,0\% (CENSO DEMOGRÁFICO 2010, 2011).

Desde a década de 1970, a expansão da pecuária e da soja em áreas do Planalto tem aumentado o desmatamento e a erosão. Pelo fato de vários rios da região, como o Taquari e o São Lourenço, apresentarem elevada capacidade de transporte de sedimentos, vêm crescendo a deposição de sedimentos no Pantanal e o consequente assoreamento dos rios localizados nas regiões de menor altitude. 


\section{Região Hidrográfica do Tocantins-Araguaia}

A Região Hidrográfica do Tocantins-Araguaia apresenta grande potencialidade para a agricultura irrigada, especialmente para o cultivo de frutíferas, de arroz e outros grãos (milho e soja). Atualmente, a necessidade de uso de água para irrigação corresponde a 62,0\% da demanda total da região e se concentra na Sub-Bacia do Araguaia devido ao cultivo de arroz por inundação. A área irrigável (por inundação e outros métodos) é estimada em 230197 hectares (CONJUNTURA..., 2013).

A Região Hidrográfica do Tocantins-Araguaia corresponde a aproximadamente 11,0\% do Território Nacional e abrange os Estados de Goiás (21,0\%), Tocantins (30,0\%), Pará (30,0\%), Maranhão (4,0\%), Mato Grosso (15,0\%), além do Distrito Federal (0,1\%). Sua configuração é alongada, com sentido Sul-Norte, seguindo a direção predominante dos cursos d'água principais, os Rios Tocantins e Araguaia, que se unem na parte setentrional da região, a partir de onde é denominado Tocantins, e que segue até desaguar na Baía da Ilha de Marajó.

Em 2013, ela concentrava 4,5\% da população nacional, sendo 76,0\% em áreas urbanas. A densidade demográfica era de $9,8 \mathrm{hab} . / \mathrm{km}^{2}$, bem menor que a densidade demográfica do País, de 22,4 hab/km² (ESTIMATIVAS..., 2013).

Na Região Hidrográfica do Tocantins-Araguaia estão presentes os Biomas Amazônia, ao norte e noroeste, e Cerrado nas demais áreas. O desmatamento da região se intensificou a partir da década de 1970, com a construção da Rodovia Belém-Brasília, da Hidrelétrica de Tucuruí e da expansão das atividades agropecuárias e de mineração. Atualmente, o desmatamento se deve principalmente à atividade de indústrias madeireiras nos Estados do Pará e Maranhão (CONJUNTURA..., 2013).

Segundo a análise feita pela ANA sobre as informações de saneamento básico do Censo Demográfico 2010, o nível de abrangência da distribuição de água apresenta realidades bastante variadas, com valores entre 1,2\% em Floresta do Araguaia, no Estado do Pará e 100\% em Novo Alegre, no Tocantins; Divinópolis do Goiás; e Araguainha, no Estado de Mato Grosso. A média regional de atendimento da população por rede de esgoto é de apenas 18,0\% e, do percentual do esgoto coletado, apenas 6,0\% é tratado (CONJUNTURA..., 2013).

\section{Região Hidrográfica Atlântico Nordeste Ocidental}

A Região Hidrográfica Atlântico Nordeste Ocidental está situada, basicamente, no Estado do Maranhão e numa pequena porção oriental do Estado do Pará. Sua área é de $274301 \mathrm{~km}^{2}$ (aproximadamente 3,2\% da área do Brasil), dos quais, cerca de 9,0\% pertencem ao Estado do Pará e 91,0\% ao Estado do Maranhão. A população total na região, em 2013, era de 6393828 habitantes, equivalente a 3,18\% da população brasileira. De acordo com o Censo Demográfico 2010, 61,0\% dessa população vive em áreas urbanas.

A região apresenta uma vazão média de $2608 \mathrm{~m}^{3} / \mathrm{s}$, ou seja, 1,0\% do total do País. As Sub-Bacias dos Rios Mearim e Itapecuru são as maiores, com áreas de 101061 km² e $54908 \mathrm{~km}^{2}$, respectivamente, onde se concentra a maior demanda por $\mathrm{m}^{3} / \mathrm{s}$ de água. 
A principal necessidade da água na bacia é para consumo humano, correspondendo a $45,0 \%$ do total. Em seguida, vem a demanda animal, com $18,0 \%$ do uso total e a demanda para irrigação, com $15,0 \%$.

De acordo com o Mapa de biomas e de vegetação do Brasil (2004b), os mais importantes ecossistemas da região são as florestas ombrófilas e estacionais, restingas, savanas (cerrados) e áreas de contato entre os diferentes tipos de vegetação. Os impactos ambientais mais significativos em função da ocupação humana são observados, atualmente, na zona de transição ocidental das áreas de floresta. Segundo a ANA, em grande parte da bacia costeira do nordeste ocidental, são utilizadas práticas agrícolas inadequadas, acarretando processos erosivos, salinização e, em alguns casos, formação de áreas desertificadas (CONJUNTURA..., 2013).

A região não enfrenta grandes problemas em relação à qualidade das águas dos rios. Isso se deve, principalmente, às localidades urbanas de pequeno e médio portes e ao parque industrial de pouca expressão. Porém, na Região Metropolitana de São Luís e em alguns núcleos urbanos ribeirinhos, a contaminação das águas pelo lançamento de esgotos sem tratamento causa perdas e restringe outros usos. Estima-se que a carga orgânica doméstica remanescente na bacia hidrográfica seja de 154 toneladas de DBO5/dia (Demanda bioquímica de oxigênio), cerca de 2,8\% do total do País (CONJUNTURA..., 2013).

\section{Região Hidrográfica do Parnaíba}

Depois da Bacia do Rio São Francisco, a Região Hidrográfica do Parnaíba é hidrologicamente a segunda mais importante da Região Nordeste. Sua área, a mais extensa dentre as 25 bacias da vertente Nordeste, abrange o Estado do Piauí e parte dos Estados do Maranhão e do Ceará. A região, no entanto, apresenta grandes diferenças inter-regionais tanto em termos de desenvolvimento econômico e social quanto em relação à disponibilidade hídrica.

A escassez de água, aliás, tem sido historicamente apontada como um dos principais motivos para o baixo índice de desenvolvimento econômico e social. Entretanto, os aquíferos da região apresentam o maior potencial hídrico da Região Nordeste e podem ser explorados de maneira sustentável, representando um grande diferencial em relação às demais áreas dessa região no que se refere à possibilidade de promover o desenvolvimento econômico e social.

A região ocupa uma área de 333056 km², o equivalente a 3,9\% do Território Nacional, e drena a quase totalidade do Estado do Piauí (99,0\%) e parte dos Estados do Maranhão (19,0\%) e Ceará (10,0\%). O Rio Parnaíba possui 1400 quilômetros de extensão. A maioria dos afluentes localizados a jusante de Teresina são perenes e supridos por águas pluviais e subterrâneas.

Os principais afluentes do Rio Parnaíba são os seguintes: Balsas, situado no Maranhão; Poti, cuja nascente localiza-se no Estado do Ceará; e Canindé, Piauí, Uruçuí-Preto, Gurguéia e Longá, todos no Estado do Piauí.

A população total da região segundo estimativa de população do IBGE, em 2013, era de 4209040 habitantes (2,09\% da população nacional) com densidade demográfica de 12,6 hab $/ \mathrm{km}^{2}$, dos quais, segundo o Censo Demográfico 2010, 35,0\% encontram-se na área rural. Há destaque para a Unidade Hidrográfica de Poti, onde se situa a capital estadual, com índice de urbanização de 92,0\%. 
O percentual da população abastecida por água, em 2010, segundo o Censo Demográfico 2010, apresentava uma média de 91,0\%, equivalente à média nacional. No entanto, a situação é crítica em relação à rede de esgotamento sanitário que apresenta um valor médio de $10,0 \%$, muito abaixo da média nacional $(62,0 \%)$.

\section{Região Hidrográfica Atlântico Nordeste Oriental}

A Região Hidrográfica Atlântico Nordeste Oriental tem uma importância singular em relação à ocupação urbana, ao contemplar cinco importantes capitais da Região Nordeste, Regiões Metropolitanas, dezenas de grandes núcleos urbanos e um parque industrial significativo. Nesse cenário, destaca-se o fato de a região abranger mais de uma dezena de pequenas bacias costeiras, caracterizadas pelas pequenas extensão e vazão de seus corpos d'água.

A região apresenta uma área de $286802 \mathrm{~km}^{2}$, equivalente a 3,3\% do território brasileiro. Uma população de 25278051 pessoas reside nessas bacias, representando 12,57\% da população do País. Seguindo a tendência de urbanização do Brasil, 80,0\% (19 167761 de habitantes) desse contingente está nas capitais e Regiões Metropolitanas de Recife, Fortaleza, Maceió, Natal e João Pessoa, além de grandes Municípios como Caruaru (PE), Mossoró (RN) e Campina Grande (PB), entre outras (ESTIMATIVAS..., 2013).

A população rural era de 4,9 milhões de habitantes, em 2010, e em toda a região encontram-se 739 sedes municipais (16,0\% do País). A distribuição da área da bacia nas Unidades da Federação é a seguinte: Piauí (1,0\%), Ceará $(46,0 \%)$, Rio Grande do Norte (19,0\%), Paraíba (20,0\%), Pernambuco (10,0\%), Alagoas (5,0\%).

A região contempla fragmentos dos Biomas Mata Atlântica, Caatinga e dos Biomas Costeiros e Insulares. Da mesma forma que em outras regiões hidrográficas costeiras, na Região Hidrográfica Atlântico Nordeste Oriental observa-se um intenso processo de povoamento desde os primórdios da colonização do Brasil. Em muitas áreas originalmente de Caatinga, a vegetação foi substituída pela pecuária. De maneira análoga, a área ocupada pelo Bioma Mata Atlântica (Zona da Mata) passou por intenso movimento de desmatamento para a implantação da cultura canavieira. Ainda hoje, o extrativismo vegetal, principalmente para exploração do potencial madeireiro, representa uma das atividades de maior impacto sobre o meio ambiente.

Em algumas áreas das bacias costeiras limítrofes com a Região Hidrográfica do São Francisco, situa-se parte do Polígono das Secas, território reconhecido pela legislação como sujeito a períodos críticos de prolongadas estiagens e diferentes índices de aridez.

\section{Região Hidrográfica do São Francisco}

Fundamental pelo volume de água transportada para o Semiárido, a Região Hidrográfica do São Francisco abrange 521 municípios em seis Estados: Bahia, Minas Gerais, Pernambuco, Alagoas, Sergipe e Goiás, além do Distrito Federal. Com 2700 km, o Rio São Francisco nasce na Serra da Canastra, no Estado de Minas Gerais, e escoa no sentido sul-norte 
pelos Estados da Bahia e Pernambuco, quando altera seu curso para o sudeste, chegando ao Oceano Atlântico na divisa entre os Estados de Alagoas e Sergipe. Devido à sua extensão e aos diferentes ambientes que percorre, a região está dividida em Alto, Médio, Sub-médio e Baixo São Francisco.

A área de drenagem ocupa 8,0\% do Território Nacional e sua cobertura vegetal contempla fragmentos de Cerrado no Alto e Médio curso, Caatinga no Médio e Submédio curso e de Mata Atlântica no Alto São Francisco, principalmente nas cabeceiras. A bacia concentra a maior quantidade e diversidade de peixes de água doce da Região Nordeste. A vazão natural média anual do Rio São Francisco é de $2846 \mathrm{~m} 3 / \mathrm{s}$, mas ao longo do ano pode variar entre $1077 \mathrm{~m}^{3} / \mathrm{s}$ e $5290 \mathrm{~m}^{3} / \mathrm{s}$.

Em 2013, 15015855 pessoas habitavam a região, segundo a estimativa de população do IBGE, o equivalente a 7,5\% da população do País, sendo a maioria habitante da Região Metropolitana de Belo Horizonte. A agricultura é uma das mais importantes atividades econômicas, mas a região possui fortes contrastes socioeconômicos, com áreas de acentuada riqueza e alta densidade demográfica e áreas de pobreza crítica e população bastante dispersa. Dos 456 municípios com sede na bacia, somente 93 tratam seus esgotos.

Como reflexo das principais atividades econômicas na região hidrográfica, há necessidade de recuperação ambiental das áreas degradadas para mitigar os impactos sobre os recursos hídricos. A região vive extremos de secas e de cheias. O semiárido, que extrapola a área da Bacia do São Francisco, é vulnerável e sujeito a períodos críticos de prolongadas estiagens, que têm sido responsáveis por êxodo de parte de sua população. Por outro lado, os moradores da Região Metropolitana de Belo Horizonte enfrentam enchentes frequentes.

Ao mesmo tempo em que possui uma abundância em termos de recursos naturais, a Região Hidrográfica do São Francisco abriga uma diversidade de culturas, de locais históricos, de sítios arqueológicos e de importantes centros urbanos. Desta forma, a associação das dimensões do Rio às belezas naturais da região e ao patrimônio cultural acumulado no decorrer dos séculos consolida um grande potencial para o desenvolvimento do turismo, atividade ainda incipiente.

O potencial hidrelétrico aproveitado da Bacia é de 10473 megawatts (MW), distribuídos principalmente nas Usinas Três Marias, Queimado, Sobradinho, Itaparica, Complexo Paulo Afonso e Xingó. Os reservatórios Três Marias e Sobradinho têm papel fundamental na regularização das vazões do Rio São Francisco. Um dos maiores desafios é que a Bacia registra todos os tipos de usos dos recursos hídricos (irrigação, geração de energia, navegação, saneamento, pesca e aquicultura, atividades turísticas e de lazer), o que exige uma análise do conjunto para que se possa planejar adequadamente sua gestão.

Estudos realizados pela ANA apontam que o crescimento da agricultura, a pretendida revitalização da navegação, o aumento da demanda energética e a retirada de água da bacia por transposição são temas que podem gerar conflitos entre os setores usuários. Em 2005, a ANA concedeu outorga para o Projeto de Integração do Rio São Francisco, que prevê duas captações (eixo norte e eixo leste) no Rio São Francisco, para complementar a oferta de água local nos Estados do Ceará, Rio Grande do Norte, Paraíba e Pernambuco. 


\section{Região Hidrográfica Atlântico Leste}

A Região Hidrográfica Atlântico Leste contempla as capitais dos Estados de Sergipe e Bahia, alguns grandes núcleos urbanos e um parque industrial significativo, estando nela inseridos, parcial ou integralmente, 526 municípios.

A região tem uma área de $388160 \mathrm{~km}^{2}$, equivalente a 4,5\% do território brasileiro. A população da Região Hidrográfica Atlântico Leste era de 16174377 habitantes, representando 8,0\% da população do País em 2013. Seguindo a tendência da distribuição populacional brasileira, 75,0\% (aproximadamente 11,2 milhões de habitantes) desse contingente encontrava-se nas cidades, principalmente nas Regiões Metropolitanas de Salvador e Aracaju (ESTIMATIVAS..., 2013). A densidade demográfica é de $41,7 \mathrm{hab} / \mathrm{km}^{2}$, enquanto a média do Brasil é de 22,4 hab/km².

Em toda a região estão situadas 468 sedes municipais (8,0\% do País). A distribuição da área da bacia nas Unidades da Federação é: Sergipe (3,8\%), Bahia (66,8\%); Minas Gerais $(26,2 \%)$ e Espírito Santo (3,2\%).

A vazão média de longo período da região é estimada em 1484 m³/s, o que representa 0,9\% do total do País.

A Região Hidrográfica Atlântico Leste comporta fragmentos dos Biomas Mata Atlântica, Caatinga, pequena área de Cerrados e, evidentemente, Biomas Costeiros e Insulares. É nessa região hidrográfica que se observa uma das maiores evoluções da ação antrópica sobre a vegetação nativa: a Caatinga foi devastada pela pecuária que invadiu os sertões; o Recôncavo Baiano e a Zona da Mata foram desmatados para a implantação da cultura canavieira; e as matas úmidas do sul da Bahia foram substituídas pelas plantações de cacau. Ainda hoje, o extrativismo vegetal, principalmente para exploração do potencial madeireiro, representa uma das atividades de maior impacto sobre o meio ambiente.

\section{Região Hidrográfica Atlântico Sudeste}

A Região Hidrográfica Atlântico Sudeste é conhecida nacionalmente pelo elevado contingente populacional e pela importância econômica de sua indústria. O grande desenvolvimento da região, entretanto, é motivo de problemas em relação à disponibilidade de água. Isso ocorre porque, ao mesmo tempo em que apresenta uma das maiores demandas hídricas do País, ela possui também uma das menores disponibilidades relativas.

Promover o uso sustentável dos recursos hídricos na região, garantindo seu uso múltiplo, representa um grande desafio. O ideal para se garantir uma melhor preservação ambiental é colocar em prática formas de gestão que conciliem o crescimento econômico e populacional com a preservação dos recursos.

A Região Hidrográfica Atlântico Sudeste tem $214629 \mathrm{~km}^{2}$ de área, equivalente a 2,5\% do País. Os seus principais Rios são o Paraíba do Sul e o Doce, com respectivamente 1150 km e $853 \mathrm{~km}$ de extensão. Além desses, a região hidrográfica também é formada por diversos e pouco extensos rios que formam as seguintes Bacias: São Mateus, Santa Maria, Reis Magos, Benevente, Itabapoana, Itapemirim, Jacu, Ribeira e litorais do Rio de Janeiro e São Paulo. 
Cerca de 29339937 pessoas habitavam a região em 2013 (14,6\% da população do País), 92,0\% das quais em áreas urbanas (ESTIMATIVAS..., 2013). Outras características demográficas marcantes da região são os significativos adensamentos populacionais, onde se destacam a Região Metropolitana do Rio de Janeiro, com mais 3000 hab $/ \mathrm{km}^{2}$. Além dessa, destacam-se as Regiões Metropolitanas de Vitória (ES) e da Baixada Santista (SP) (Mapa 3).

Em relação ao uso e à ocupação do solo, um dos principais problemas se refere à ocupação irregular de encostas, áreas ribeirinhas e de mananciais, estimulada em grande parte pela especulação imobiliária. Devido ao intenso e desordenado processo de uso e ocupação, podem ser encontrados, ao longo dos rios, apenas pequenos trechos com vegetação ciliar e geralmente em mau estado de conservação.

\section{Região Hidrográfica do Paraná}

A Região Hidrográfica do Paraná, com 32,0\% da população nacional, apresenta aquela de maior desenvolvimento econômico do País. Com uma área de 879873 km², abrange os Estados de São Paulo (25,0\% da região), Paraná (21,0\%), Mato Grosso do Sul (20,0\%), Minas Gerais $(18,0 \%)$, Goiás $(14,0 \%)$, Santa Catarina (1,5\%) e o Distrito Federal (0,5\%).

Em 2013, segundo a estimativa de população do IBGE, 64322182 pessoas viviam na região, sendo 93,0\% em áreas urbanas (CENSO DEMOGRÁFICO 2010, 2011). A região abriga a cidade mais populosa da América do Sul, São Paulo, com cerca de 11,1 milhões de habitantes. Outros importantes centros populacionais são: Brasília, Curitiba, Goiânia, Campinas, Campo Grande e Uberlândia. A maior parte de população se concentra nas Unidades Hidrográficas dos Rios Tietê e Grande, que, juntas, correspondem a 61,0\% da população total.

O crescimento de grandes centros urbanos, como São Paulo, Curitiba e Campinas, em rios de cabeceira, tem gerado uma grande pressão sobre os recursos hídricos. Isso ocorre porque, ao mesmo tempo em que aumentam as demandas, diminui a disponibilidade de água devido à contaminação por efluentes domésticos, industriais e drenagem urbana.

Originalmente, a Região Hidrográfica do Paraná apresentava os Biomas Mata Atlântica e Cerrado e cinco tipos de fisionomias de vegetação: savana (ou cerrado), floresta ombrófila densa, floresta estacional semidecidual, floresta estacional decidual (conhecidas vulgarmente como Mata Atlântica) e floresta ombrófila mista (ou Mata de Araucária). O uso do solo na região passou por grandes transformações ao longo dos ciclos econômicos do País, o que ocasionou um grande desmatamento.

Essa região hidrográfica possui a maior demanda por recursos hídricos do País, equivalente a $736 \mathrm{~m}^{3} / \mathrm{s}$, que corresponde a $31,0 \%$ da demanda nacional. A irrigação é a maior usuária de recursos hídricos (42,0\% da demanda total), seguida do abastecimento industrial $(27,0 \%)$.

Com relação ao saneamento, de acordo com o Censo Demográfico 2010, os percentuais da população atendida com abastecimento de água variavam de 90,0\% (Paranaíba) a $98,0 \%$ (Grande). A maioria das unidades hidrográficas está com um percentual acima da média do Brasil que era de $91,0 \%$. O percentual da população atendida com rede coletora de esgotos nas unidades hidrográficas variavam entre 38,0\% (Piriqui) e 96\% (Grande). Os percentuais de tratamento de esgotos variavam de 33,0\% (Piriqui) e 97,0\% (Paranapanema), enquanto a média nacional era de 30,0\%. 


\section{Região Hidrográfica Atlântico Sul}

A Região Hidrográfica Atlântico Sul destaca-se por abrigar um expressivo contingente populacional, pelo desenvolvimento econômico e por sua importância para o turismo. A região se inicia ao norte, próximo à divisa dos Estados de São Paulo e Paraná e se estende até o Arroio Chuí, ao sul. Possui uma área total de 187522 km², o equivalente a 2,2\% do País.

Abrangendo porções dos Estados do Paraná, Santa Catarina e Rio Grande do Sul, a região tinha, em 2013, 13574899 habitantes (6,75\% da população nacional), sendo que 88,0\% em área urbana (ESTIMATIVAS..., 2013). Ela abriga 451 municípios e 411 sedes municipais, entre os quais destacam-se, no contexto socioeconômico: Paranaguá, no Estado do Paraná; Joinville e Florianópolis, no Estado de Santa Catarina; e Caxias do Sul, Santa Maria, Pelotas e a Região Metropolitana de Porto Alegre, no Estado do Rio Grande do Sul. A população da região está concentrada, principalmente, nas Unidades Hidrográficas Litoral de Santa Catarina e Guaíba.

Em 2010, os dados de saneamento mostravam que 91,0\% da população era abastecida por água, valor equivalente à média nacional. As unidades hidrográficas da região apresentavam índices de atendimento da população por esgoto que variavam entre $37,0 \% \mathrm{e}$ $70,0 \%$. O nível de esgoto tratado era baixo, apresentando valores entre 10,0 e 19,0\% (CENSO DEMOGRÁFICO 2010, 2011).

Sob intensa e histórica ação antrópica, a Mata Atlântica, vegetação original predominante nesta região hidrográfica, estendia-se desde o Estado de São Paulo até o norte do Estado do Rio Grande do Sul.

\section{Região Hidrográfica do Uruguai}

A Região Hidrográfica do Uruguai tem importância para o País em função das atividades agroindustriais desenvolvidas e de seu potencial hidrelétrico. O Rio Uruguai possui 2200 km de extensão e se origina da confluência dos Rios Pelotas e Canoas. Nesse trecho, o rio assume a direção leste-oeste, dividindo os Estados do Rio Grande do Sul e Santa Catarina. A bacia hidrográfica totaliza, em território brasileiro, $174533 \mathrm{~km}^{2}$ de área, o equivalente a 2,0\% do Território Nacional.

Em função das suas características hidrológicas e dos principais rios formadores, a área foi dividida em 13 unidades hidrográficas, sendo quatro no Estado de Santa Catarina e nove no Estado do Rio Grande do Sul. Em 2013, 4136331 pessoas viviam na parte brasileira da Região Hidrográfica do Uruguai (2,1\% da população do País), com maior concentração nas Unidades Hidrográficas de Chapecó, Canoas, Ibicuí e Turvo.

Na região existem atualmente 384 municípios, dos quais merecem destaque Lages e Chapecó, no Estado de Santa Catarina; Erechim, ljuí, Uruguaiana, Santana do Livramento e Bagé, no Estado do Rio Grande do Sul.

Os números do saneamento básico (CENSO DEMOGRÁFICO 2010, 2011) são também importantes para a caracterização da Região. Em relação à parcela de população abastecida 
de água, com exceção das Unidades Hidrográficas Ijuí, Quaraí, Santa Maria e Negro, todas as demais apresentavam, em 2010, valores abaixo da média nacional (91,0\%). O valor médio de atendimento pela rede de esgoto na região é de 33,0\%. A porcentagem de esgoto tratado nas unidades hidrográficas era muito baixa, com média de 10,0\%, inferior, portanto, à média brasileira $(30,0 \%)$.

Em relação à vegetação, a bacia apresentava, originalmente, nas nascentes do rio Uruguai, estepes (ou campos) e floresta ombrófila mista (mata com Araucária) e, na direção sudoeste, as estepes e floresta estacional decidual (Mata do Alto Uruguai e Mata Atlântica). Segundo a ANA, atualmente, a região encontra-se intensamente desmatada e apenas regiões restritas conservam remanescentes da vegetação original (CONJUNTURA..., 2013).

\section{Regiões hidrográficas no contexto dos biomas brasileiros}

Outra forma de contextualizar os recursos hídricos no Território Nacional diz respeito à leitura conjugada de duas regiões naturais que, de modo muito particular, têm nos recursos hídricos um atributo essencial na definição/delimitação de suas fronteiras: a divisão regional do Brasil em biomas e em regiões hidrográficas.

Com efeito, por um lado, o bioma, de acordo com o IBGE, é um conjunto de vida (vegetal e animal) constituído pelo agrupamento de tipos de vegetação contíguos e identificáveis em escala regional (Tabela 3/Mapa5), com condições geoclimáticas similares e história compartilhada de mudanças, o que resulta em uma diversidade biológica própria (MAPA..., 2004b).

Por outro lado, a disponibilidade de água é uma das condições determinantes para o desenvolvimento e predominância de tipos específicos de vegetação e da biodiversidade como um todo, sendo, portanto, pertinente avaliar essa disponibilidade nos diversos biomas que ocorrem no Brasil (Mapa 5).

Tabela 3 - Área aproximada dos biomas, total e percentual em relação ao Território Nacional 2004

\begin{tabular}{l|r|r}
\hline \multirow{2}{*}{ Biomas continentais } & \multicolumn{2}{c}{ Área aproximada dos biomas } \\
\cline { 2 - 3 } \multicolumn{1}{c|}{ Total } & Total $\left(\mathrm{km}^{2}\right)$ & \multicolumn{1}{c}{ Percentual (\%) } \\
Amazônia & $\mathbf{8 5 1 4 8 7 7}$ & $\mathbf{1 0 0 , 0 0}$ \\
Cerrado & 4196943 & 49,29 \\
Mata Atlântica & 2036448 & 23,92 \\
Caatinga & 1110182 & 13,04 \\
Pampa & 844453 & 9,92 \\
Pantanal & 176496 & 2,07 \\
& 150355 & 1,76 \\
\hline
\end{tabular}

Fonte: Mapa de biomas e de vegetação. Rio de Janeiro: IBGE, 2004. Disponível em: <https://www.ibge.gov.br/home/presidencia/ noticias/21052004biomashtml.shtm>. Acesso em: maio 2016. 
Mapa 5 - Biomas e regiões hidrográficas - 2004

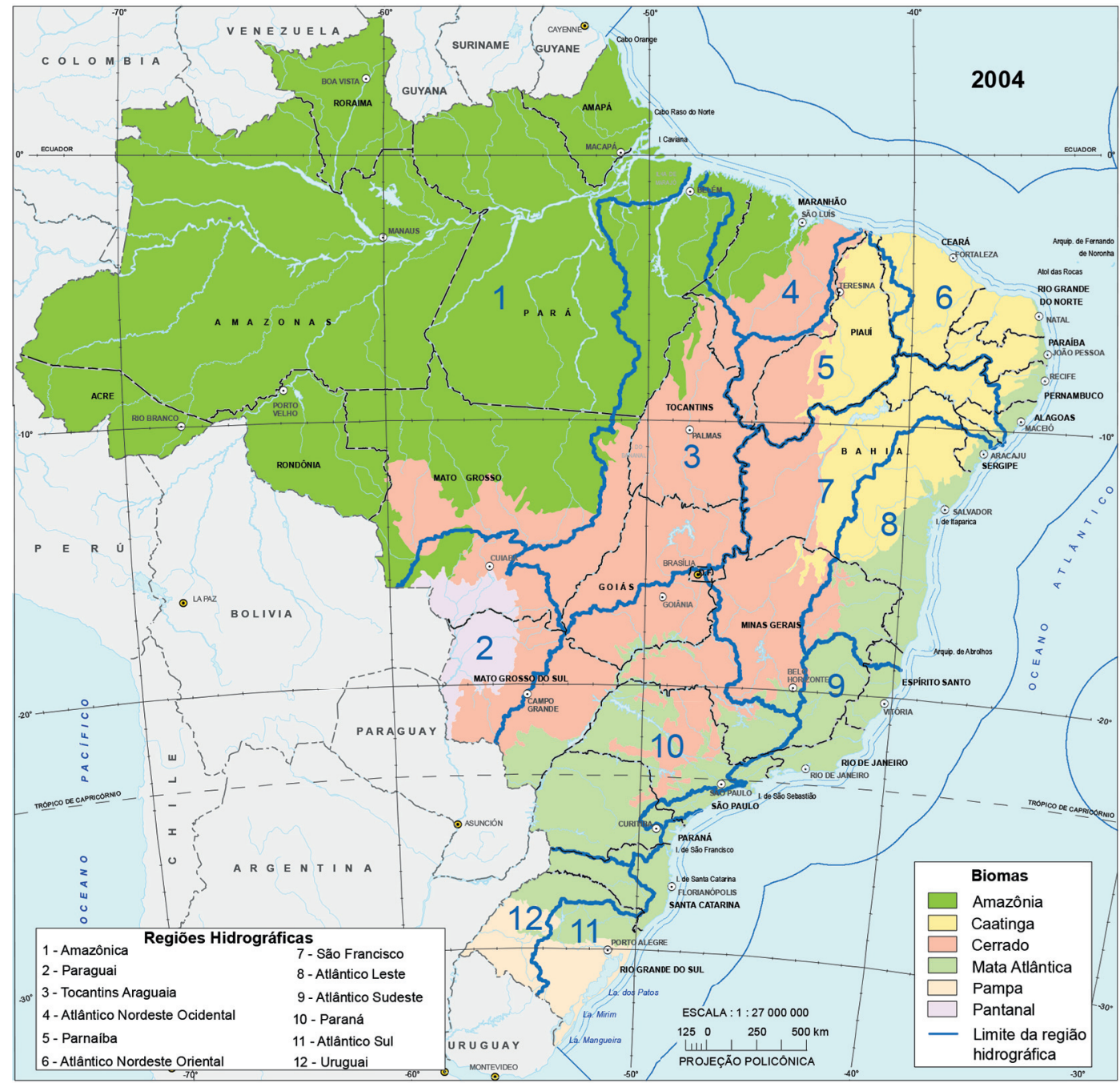

Fontes: 1. Mapa de biomas do Brasil: primeira aproximação. Rio de Janeiro: IBGE, 2004. Escala 1:5 000 000. 2. Conselho Nacional de Recursos Hídricos (Brasil). Resolução n. 32, de 15 de outubro de 2003. Brasília, DF, 2003. Disponível em: <http://www. cnrh.gov.br/index.php?option=com_content\&view=article\&id=14>. Acesso em: maio 2016. 


\section{Regiões hidrográficas e biomas brasileiros}

Amazônia: A Amazônia é o bioma brasileiro de maior extensão superficial, possuindo um território de 4196943 milhões de km² (MAPA..., 2004a) que corresponde a 1/3 das florestas tropicais do mundo. Esse bioma ocupa a porção norte do território brasileiro, abrangendo os Estados do Acre, Amapá, Amazonas, Pará, Rondônia, Roraima e ainda uma porção dos Estados do Maranhão, Tocantins e Mato Grosso.

A relação com a disponibilidade hídrica é evidente, uma vez que seus rios representam cerca de 20,0\% das reservas de água doce do planeta, estabelecendo-se, por conseguinte, uma dependência entre os seus diversos ecossistemas e a presença de um grande volume de água que compreende, além da floresta úmida de terra firme, diferentes tipos de matas, campos abertos e até espécies de cerrado.

A Bacia Amazônica é a maior bacia hidrográfica do mundo: cobre cerca de 6 milhões de km² e tem 1100 afluentes. Seu principal rio, o Amazonas, corta a região para desaguar no Oceano Atlântico, lançando ao mar cerca de 175 milhões de litros d'água a cada segundo (BIOMAS, 2015).

A função ecológica de uma floresta do porte da Floresta Amazônica está intimamente relacionada com o clima e ao ciclo hidrológico, tendo em vista a regulação climática de todo nosso planeta, seja por meio da retenção de carbono atmosférico, seja por meio da evapotranspiração e dispersão de chuvas para todo o continente sul-americano. A floresta acompanha em grande medida os principais rios da Bacia do Amazonas, desde o sopé dos Andes até o Atlântico.

Caatinga: A Caatinga é o bioma predominante na Região Nordeste do Brasil e o mais árido de todos. Com uma superfície de 844453 km², ele cobre cerca de 10,0\% do Território Nacional e ocorre no interior da Região Nordeste, desde o Estado da Bahia até o Estado do Maranhão. Sua vegetação típica é seca e espinhosa por causa da falta de chuvas durante grande parte do ano. Porém, quando chega o período de chuvas, as folhagens voltam a brotar e a paisagem fica mais verde.

No contexto da disponibilidade de água através da precipitação, destaca-se a questão do déficit hídrico na maior parte da área abrangida pelo bioma. O clima na região varia do superúmido (com pluviosidade em torno de 2000 mm/ano), num pequeno trecho, até o semiárido, em área maior, com pluviosidade entre 300-500 mm/ano e chuvas restritas a poucos meses durante o ano. As plantas desenvolveram adaptações únicas para enfrentar a aridez. Na estação seca, caem as folhas da maioria das árvores e os troncos aparecem esbranquiçados (PRADO, 2003 apud MONITORAMENTO..., 2011a). A paisagem reflete essa aridez, dominada por uma vegetação arbustiva, ramificada e espinhosa, com muitas bromeliáceas, euforbiáceas e cactáceas (COIMBRA FILHO; CÂMARA, 1996 apud MONITORAMENTO..., 2011a). As florestas mais úmidas, chamadas brejos de altitude, estendem-se sobre as encostas e topos das chapadas e serras com mais de $500 \mathrm{~m}$ de altitude, que recebem mais de $1200 \mathrm{~mm}$ de chuvas (ANDRADE LIMA, 1982; PRADO, 2003 apud MONITORAMENTO..., 2011a). 
O aumento da altitude é um dos fatores que controla a quantidade de chuva e modifica a paisagem geral do bioma: as serras variam de $1000 \mathrm{~mm}$ a $2000 \mathrm{~mm}$ e as chuvas chegam a 1500 mm/ano, o que é de suma importância para a vegetação e a fauna e para a exploração humana dos recursos naturais. Cortada por dois grandes rios caudalosos e perenes (os Rios Parnaíba e São Francisco) e por outros rios menores e em grande parte temporários, muito da água usada pelas pessoas que habitam a Caatinga vem de açudes. Isso é importante especialmente porque ali chove menos de 600 milímetros $(\mathrm{mm})$ anuais, em geral, nos meses iniciais do ano.

Pantanal: O Pantanal é a ligação entre o Cerrado (na Região Centro-Oeste), o Chaco (na Bolívia) e a Região Amazônica (na Região Norte do País). Segundo o Ministério do Meio Ambiente, o Bioma Pantanal é considerado uma das maiores extensões úmidas contínuas do planeta e sofre influência direta de três importantes biomas brasileiros: Amazônia, Cerrado e Mata Atlântica (BIOMAS, 2015). Como é uma área de transição, a região é formada por uma variedade de ecossistemas que são periodicamente inundados, apresentando, por isso, fauna bastante diversificada. Segundo Alho (2005 apud MONITORAMENTO..., 2011d), as influências dos outros biomas propiciam as diferenças climáticas, o que ocasiona diversas características dos rios e solos, formando diferentes sub-regiões ou tipos de pantanais.

O Bioma Pantanal constitui a maior área continental periodicamente alagável do planeta. Ele possui $150355 \mathrm{~km}^{2}$ e se entende não somente pelo Território Nacional, mas também pela Bolívia e Paraguai. O Pantanal é um imenso reservatório de água, constituindo passagem obrigatória de grande parte do fluxo que percorre a Bacia do Prata.

O lento ciclo das cheias e vazantes, conhecido como pulso de inundação, cria um variado mosaico de paisagens. As baías, denominadas as lagoas pantaneiras, são os elementos mais peculiares da região. Elas compõem a paisagem com rios tortuosos, campos alagáveis, matas ciliares, capões de matas, salinas e corixos (nome regional para os riachos da planície) formando os diferentes habitats pantaneiros. Toda essa variedade de ambientes dominada pela água sustenta uma diversa fauna de peixes de pequeno a grande porte, aves e mamíferos.

O clima do Pantanal é predominantemente tropical continental marcado pelas altas temperaturas e grande índice pluviométrico, um verão quente e chuvoso e um inverno frio e seco. Dessa maneira, na época das chuvas, ou seja, no verão, o Pantanal fica praticamente intransitável por terra; enquanto no período da seca, no inverno, os rios secam e sobra o barro, daí seu nome "Pantanal".

Todos os habitantes do Pantanal têm suas vidas marcadas pelo eterno ciclo das águas, desde o dourado, um peixe de escamas, até o ribeirinho. O início do período chuvoso ocorre, geralmente, de outubro a março com precipitação média de $1200 \mathrm{~mm}$ a $1400 \mathrm{~mm}$ e a estação de seca, entre abril e setembro. O ciclo hidrológico e a dinâmica hídrica do bioma são condicionantes importantes que garantem a alta biodiversidade e possibilitam o funcionamento ecológico de toda região (IMPLEMENTAÇÃO..., 2004 apud MONITORAMENTO..., 2011d). As planícies de inundação constituem terras planas que são inundadas quando o escoamento superficial excede a capacidade normal do canal (BARELLA et al., 2001 apud MONITORAMENTO..., 2011d). 
O Pantanal é cercado por uma série de serras. É isso que o torna um reservatório de água a temperaturas quentes, uma concentração de vida. No entanto, toda essa água chega ao Pantanal depois de transitar desde nascentes por toda a sua volta, ou seja, a inundação do Pantanal depende das águas que são trazidas das cabeceiras dos rios do planalto. $\mathrm{O}$ escoamento, ao deixar o planalto, é de largura estreita, portanto, o fluxo extravasa o leito, inundando a planície e preenchendo as depressões na qual formam baías e lagoas (ALHO, 2003 apud MONITORAMENTO..., 2011d).

A expansão desordenada das atividades agropecuárias na região do Pantanal tem contribuído para a degradação dos ambientes naturais (com perda de biodiversidade), para intensificação da erosão laminar e do assoreamento e para contaminação dos rios com biocidas (SANTOS, 2006 apud MONITORAMENTO...,, 2011d). Os desequilíbrios acarretam prejuízos para a exploração agropecuária, para setores socioeconômicos e principalmente para o meio ambiente (GALDINO; VIEIRA; SORIANO, 2003 apud MONITORAMENTO..., 2011d).

São também consideradas ameaças à conservação dos ecossistemas e processos ecológicos no Pantanal os projetos de infraestrutura (hidrelétricas, hidrovias, mineradoras), a caça, a invasão de espécies exóticas e a poluição resultante do uso de pesticidas nas áreas agrícolas localizadas nas cabeceiras dos principais rios que drenam a planície (ALHO et al., 1988 apud MONITORAMENTO..., 2011d), o que causa, dentre outras consequências, o assoreamento e a mudança da trajetória dos corpos d'água, descaracterização da paisagem e a contaminação das bacias.

Cerrado: O Cerrado é considerado o segundo maior bioma brasileiro em extensão, distribuindo-se por todo o Brasil Central, com uma área original de $2036448 \mathrm{~km}^{2}$, aproximadamente 20,0\% do território do País. Localizando-se principalmente no Planalto Central brasileiro, é um ecossistema similar às Savanas de outros continentes, abrangendo os seguintes Estados: Amapá, Maranhão, Piauí, Rondônia, Distrito Federal, Goiás, Mato Grosso, Mato Grosso do Sul, Minas Gerais, São Paulo, Tocantins e Bahia.

A relação entre a disponibilidade hídrica e o ciclo de vida de sua vegetação é bastante estreita, uma vez que, durante seis meses, o Cerrado torna-se verdejante devido às frequentes chuvas que vão de outubro a abril. Nos meses restantes, torna-se pronunciadamente seco e susceptível a queimadas, às vezes espontâneas.

Segundo a classificação climática adotada no Brasil, o clima do Bioma Cerrado é o tropical sazonal de inverno seco com temperatura média anual em torno de $22-23^{\circ} \mathrm{C}$. A precipitação medial anual varia entre $1200 \mathrm{~mm}$ a $1800 \mathrm{~mm}$. Entre maio e setembro, os índices pluviométricos reduzem-se e a umidade relativa do ar fica entre 10,0 a 30,0\%, podendo haver secas prolongadas (MONITORAMENTO...,, 2011b).

No Cerrado, encontram-se as nascentes das três maiores bacias hidrográficas da América do Sul (Amazônica/Tocantins, São Francisco e Prata), o que resulta em um elevado potencial aquífero e favorece a biodiversidade da região (BIOMAS, 2015).

Segundo o Ministério do Meio Ambiente, depois da Mata Atlântica, o Cerrado é o bioma brasileiro que mais sofreu alterações com a ocupação humana (MONITORAMENTO..., 2011b). A pressão sobre a biodiversidade e sobre os recursos hídricos estão ligadas à mudança 
de cobertura e uso da terra devido à crescente pressão para incrementar a produção de carne e grãos, voltados principalmente aos mercados externos, o que acarreta um progressivo esgotamento dos recursos naturais da região, entre eles a água. Nas três últimas, décadas esse processo tem caracterizado o Cerrado como palco da expansão da fronteira agrícola brasileira.

Mata Atlântica: Cerca de 70,0\% da população brasileira concentra-se na Mata Atlântica, que abrange 15 estados brasileiros das Regiões Sul, Sudeste, Centro-Oeste e Nordeste. (LEVANTAMENTO..., 2007 apud MONITORAMENTO..., 2012).

Segundo o Ministério do Meio Ambiente, a Mata Atlântica constitui o bioma brasileiro com menor porcentagem de cobertura vegetal natural, possuindo, no entanto, uma relevante parte da diversidade biológica do País com várias espécies endêmicas (MONITORAMENTO..., 2012). A porcentagem de $7,0 \%$ restante da cobertura florestal original $\left(1200000 \mathrm{~km}^{2}\right.$ de floresta de grande porte) é um fato agravado porque os recursos hídricos (rios) abastecem mais de 120 milhões de brasileiros, com remanescentes que regulam o fluxo dos mananciais hídricos, asseguram a fertilidade do solo, controlam o clima e protegem escarpas e encostas das serras (LEVANTAMENTO..., 2007 apud MONITORAMENTO..., 2012).

Sua ocupação histórica remonta aos principais ciclos econômicos que levaram a uma intensa perda desse bioma.

Seu relevo é acidentado e o solo raso, frequentemente ocorrendo o afloramento das rochas. Uma floresta tão exuberante é sustentada pela alta umidade trazida do oceano e deixada na Serra do Mar.

A disponibilidade hídrica varia também em função das grandes variações de altitude e latitude. A Mata Atlântica se expressa em diferentes formações vegetais e paisagens: floresta ombrófila densa, restingas, manguezais, campos de altitude naturais, refúgios vegetacionais, áreas de várzea e dunas. A floresta ombrófila densa, por exemplo, luxuriante e biodiversa formação florística existente próxima ao mar, se desenvolve em toda sua plenitude nas áreas mais úmidas. Mais para o interior do País, a floresta apresenta formações que perdem parcialmente as folhas no período de seca, a Mata Atlântica de planalto.

Pampas: De maneira genérica, os campos da Região Sul do País são chamados de "Pampas", denominação que corresponde somente aos tipos de campo encontrados num único Estado: o Rio Grande do Sul (63,0\%), estendendo-se também pelo Uruguai e Argentina. Em outras partes da região, encontram-se as matas de araucárias e, também, campos semelhantes à savana. Segundo o Ministério do Meio Ambiente, a vegetação torna-se mais densa próxima aos cursos d'água e nas encostas de planaltos (MONITORAMENTO..., 2011c). A precipitação anual fica em torno de 1200 mm, com pouca variação sazonal. A pecuária é a principal atividade econômica da região devido à fertilidade do solo (outras atividades impactantes são as lavouras de arroz em áreas de banhado e o plantio de eucalipto). No entanto, há também a ocorrência de solos arenosos na região do Município de Alegrete, o que inspira maiores cuidados em seu manejo para que não haja desertificação. 
A disponibilidade hídrica é alta, tendo em vista que a Região Sul do Brasil, onde este bioma se localiza, caracteriza-se pela abundância e boa distribuição das chuvas. Os processos de degradação das terras e desertificação que ocorrem estão assim muito mais ligados a fatores de manejo do que ao déficit hídrico.

No litoral, o Banhado do Taim e as lagoas costeiras (como a Lagoa dos Patos) formam ambientes salobros, únicos no País. Esses banhados e lagoas abrigam espécies endêmicas e populações expressivas de aves aquáticas.

O relevo apresenta topos mais planos, vegetação rala e pobre em espécies, que se torna mais densa e rica nas encostas, com predominância de gramíneas e leguminosas. Segundo o Ministério do Meio Ambiente, o bioma exibe um imenso patrimônio cultural associado à biodiversidade. Em sua paisagem predominam os campos, entremeados por capões de mata, matas ciliares e banhados (BIOMAS, 2015).

Os Pampas, ou campos sulinos, estão adaptados ao clima mais frio do Brasil, com temperaturas eventuais abaixo de zero, geadas e até neve. Estimam-se o número das espécies vegetais em 3 000, das quais nada menos que 400 de gramíneas.

A análise da geografia dos recursos hídricos no Brasil não se esgota, contudo, na leitura conjugada das 12 regiões hidrográficas e dos seis biomas coexistentes no território brasileiro. Ao contrário, ela se completa e se complexifica quando se leva em conta um novo recorte regional do País agora focado na distribuição espacial das águas subterrâneas.

\section{Recursos hídricos subterrâneos do Brasil}

Da mesma forma que os recursos hídricos superficiais, os recursos hídricos subterrâneos são imprescindíveis ao atendimento das necessidades do País. A Hidrogeologia é o ramo da Geologia que estuda as águas subterrâneas, ou seja, tem como foco a parcela do ciclo hidrológico que se infiltra no solo e percola em subsuperfície, formando os aquíferos (unidades geológicas capazes de armazenar e produzir águas subterrâneas).

Águas subterrâneas abastecem nascentes, rios, pântanos e lagoas. Por isso, mesmo na época seca, a maioria dos nossos rios é perene. Os aquíferos têm importância estratégica e suas funções são ainda pouco exploradas seja no campo da produção, armazenamento, circulação, regularização, filtragem e autodepuração, além daquelas no campo do abastecimento e manutenção dos ecossistemas aquáticos.

A conjugação de fatores geológicos (litologia, estratigrafia, estrutura e tectônica), geomorfológicos e climáticos serve como parâmetro para definir regiões onde os sistemas aquíferos apresentam condições hidrogeológicas semelhantes (armazenamento, circulação, descarga e qualidade química das águas). Essas grandes regiões são denominadas províncias hidrogeológicas (Mapa 6). 


\section{Mapa 6 - Águas subterrâneas nas províncias hidrogeológicas}

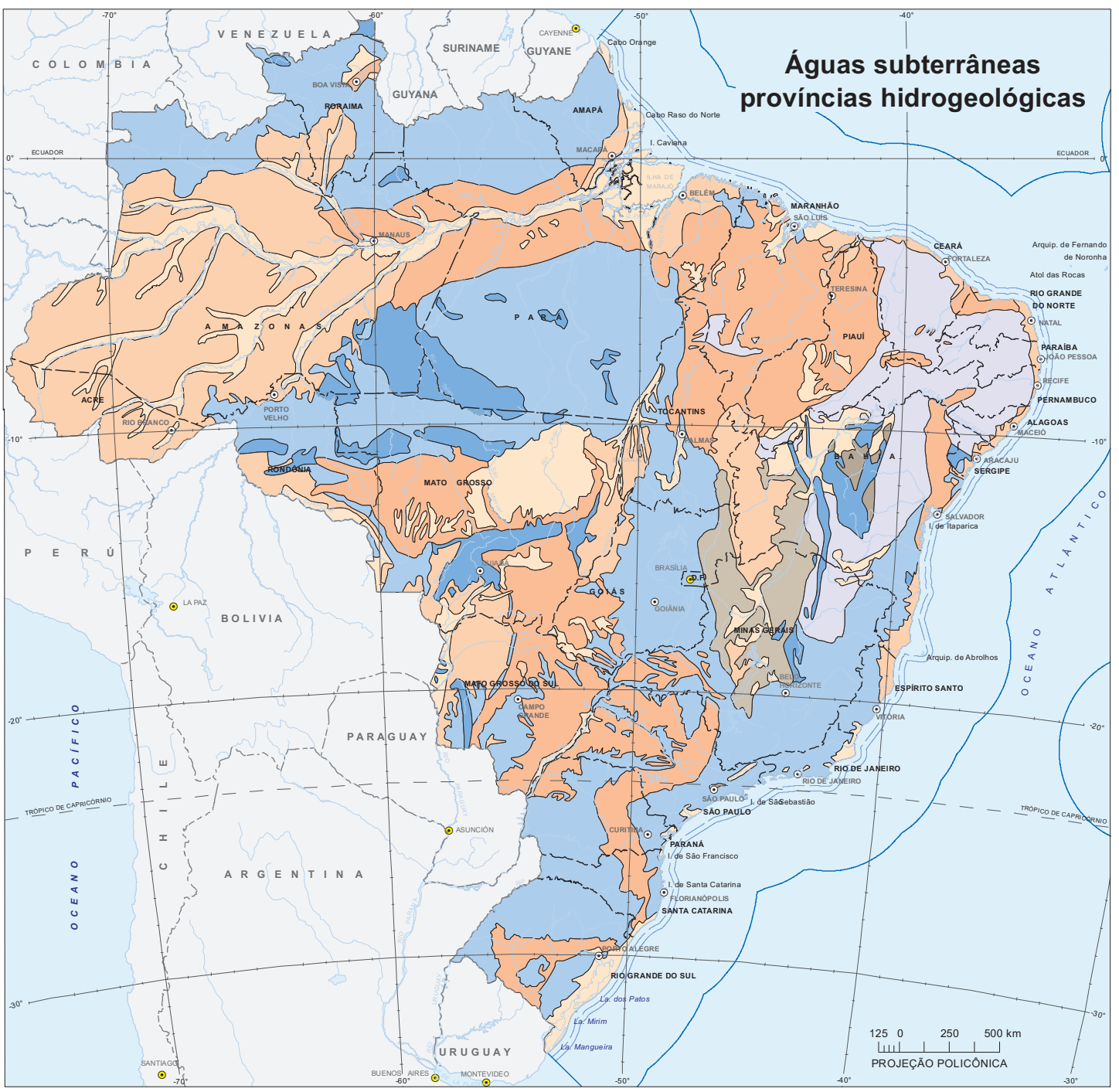

Província intergranular Aquíferos contínuos, de extensão regional. constituídos por sedimentos clásticos. Reune litologias e estruturas altamente
favoráveis à acumulaçãa de abundantes recursos hídricos, em condições livres e artesianas. Exploração por poços profundos. Qualidade química das águas geralmente boa. Importância hidrogeológica relativa, grande.

Aquíferos contínuos, de extensão variável. livres e/ou semi-confinados, constituídos por sedimentos clásticos pouco consolidados. Permeabilidade fraca a média. Qualidade química das águas geralmente boa. Importância hidrogeológica relativa, média.

Aquiferos livres, de extensão restrita e espessuras reduzidas, constituídos por sedimentos clásticos não consolidados. Permeabilidade média. Exploração por poços rasos. Qualidade química das águas geralmente boa. Importância hidrogeológica relativa, pequena.

\section{Província fissural}

Aquiferos locais, fraturados e/ou com certa porosidade intersticial. Formados por rochas metaclásticas (metarenitos, quartzitos, etc.). Permeabilidade média. Qualidade química das águas geralmente boa. Importância hidrogeológica relativa, média.

Aquiferos locais, em rochas cristalinas (igneas e matamórficas),com circulação hídrica subterrânea restrita aos sistemas de fraturamento. Recarga (pluviometria) regular a elevada. Qualidade química das águas boa a ligeiramente salina. Importância hidrogeológica relativa pequena a média.

Aquiferos locais, livres, em rochas cristalinas (ígneas e matamórficas), com circulação hídrica subterrânea restrita às zonas fraturadas. Recarga (pluviometria) irregular e reduzida. Águas em geral salinizadas. Poços com baixa produtividade. Importancia hidrogeológica relativa pequena a muito pequena.

\section{Província cárstica}

Aquiferos locais, francamente cársticos, formados por rochas carbonáticas. As zonas fraturadas foram ampliadas pela dissoluça carsticas, dando origem a cavernas, dolinas e rios subterrâneos. Aguas geralmente duras (alto teor de CaCo3). Importancia hidrogoologica selativa, media .

Constituidos por rochas carbonáticas e metapelíticas. Permeabilidade baixa a média. Águas ligeiramente salinas. Importância hidrogeológica relativa, pequena.

Fontes: 1. Ministério de Minas e Energia, Departamento Nacional de Produção Mineral - DNPM. 2. IBGE, Diretoria de Geociências, Coordenação de Recursos Naturais e Estudos Ambientais. Extraído de: Atlas nacional do Brasil Milton Santos. Rio de Janeiro: IBGE, 2010. Disponível em: <http://biblioteca.ibge.gov. br/index.php/biblioteca-catalogo? iew $=$ detalhes\&id $=247603>$. Acesso em jun. 2016. 
No território brasileiro, as águas subterrâneas estão abrigadas em diferentes tipos de reservatórios, que vão desde as zonas fraturadas do embasamento cristalino até os depósitos sedimentares mais recentes. Esses sistemas aquíferos podem ser agrupados em três grandes províncias hidrogeológicas: intergranular (porosa), fissural e cárstica.

\section{Províncias hidrogeológicas do Brasil}

A Província Intergranular ou Porosa é formada por rochas sedimentares e ocupa cerca de 48,0\% da área total do País, compreendendo vários sistemas aquíferos, como: Amazonas (Alter do Chão, Solimões e Boa Vista), Parecis, Paraná (Guarani, Bauru, Tubarão, Ponta Grossa e Furnas), Parnaíba (Serra Grande, Cabeças, Poti-Piauí, Motuca, Corda e Itapecuru), Recôncavo-Tucano-Jatobá (Marizal, São Sebastião, Tacaratu e Sergi), Potiguar (Açu-Jandaíra), Paraíba-Pernambuco (Beberibe), Araripe (Missão Velha), Sergipe-Alagoas, (Marituba), São Francisco (Urucuia-Areado), São Luís-Barreirinhas, São Paulo e Taubaté, além do Grupo Barreiras e Coberturas Cenozóicas.

A Província Fissural ocupa pouco mais de 50,0\% do território brasileiro, sendo constituída por uma associação de rochas ígneas, metavulcanossedimentares e vulcânicas (granitos, gnaisses, granodioritos, migmatitos, anfibolitos, xistos, basaltos, diabásios, etc). Caracteriza-se pelo modo peculiar de circulação de suas águas - através de fraturas. Podem ser também incluídas, nessa província, as rochas metassedimentares (metarenitos, metassiltitos, quatzitos), que apesar de apresentarem características de aquífero misto (poroso-fissural), comportam-se muito mais como um aquífero do tipo fissural. São dignas de registro as ocorrências de rochas metassedimentares nos Estados de Minas Gerais, Bahia e Sergipe (Supergrupo Espinhaço e Faixa de Dobramentos Sergipana).

O fato de os aquíferos fissurais possuírem pontos de recarga e vias de circulação restritos às fraturas torna-os pouco produtivos, especialmente na Região Nordeste, onde a recarga é deficiente em função dos índices pluviométricos reduzidos. Este fato repercute na grande incidência de poços secos ou com vazões reduzidas, em geral produzindo águas salinas; influencia também o caráter intermitente de boa parte da rede de drenagem, devido à reduzida parcela destinada à restituição subterrânea. Já na Região Sul, por exemplo, os basaltos da formação Serra Geral constituem aquíferos importantes regionais e são largamente explorados.

A Província Cárstica compreende os depósitos desenvolvidos em rochas de natureza carbonática (calcários), onde os condutos aquíferos (fraturas) foram ampliados pela dissolução cárstica (fenômeno provocado pelas águas das chuvas e dos rios em regiões calcárias), dando origem a cavernas, sumidouros, dolinas e outras feições erosivas características. Aquíferos dessa natureza ocorrem com destaque nos Estados da Bahia, Minas Gerais, Goiás e Rio Grande do Norte.

A qualidade da água subterrânea em algumas regiões hidrográficas reveste-se de suma importância, particularmente em situações de clima semiárido onde a disponibilidade de águas superficiais é limitada e sujeita a grande variabilidade sazonal. 
O detalhamento de aspectos da hidrogeologia da Região Nordeste é apresentado em seguida por ser tal informação crucial nessa região do País, tanto para o abastecimento da população quanto para o desenvolvimento das atividades nos diversos setores de sua economia.

\section{Hidrogeologia da Região Nordeste}

Os nove estados que compõem a Região Nordeste do Brasil somam uma área de 1554257 km², dos quais cerca de 60\% correspondem ao Polígono das Secas - região onde predominam condições climáticas semiáridas, que se manifestam através da ocorrência de precipitações pluviométricas escassas e irregulares e extensos períodos anuais de forte insolação e evaporação, responsáveis por uma acentuada deficiência hídrica.

Nesta região é bastante comum a ocorrência de secas - muitas delas calamitosas -, cujas consequências determinam repetidos danos à agricultura e à pecuária, desencadeando problemas sociais e econômicos. Essas dificuldades naturais reforçam a importância de se conhecer as principais características dos reservatórios subterrâneos e a qualidade das águas da região.

Especificamente no que tange à abrangência do Polígono das Secas, temos grande parte da Região Hidrográfica do Parnaíba e parcelas significativas da Regiões Hidrográficas Atlântico Nordeste Oriental e São Francisco, estendendo-se também para algumas áreas da Atlântico Nordeste Ocidental e Atlântico Leste.

Considerando que boa parte da Região Nordeste está submetida ao clima semiárido, os recursos hídricos subterrâneos avultam em importância, sobretudo por representarem um manancial naturalmente protegido dos efeitos da estiagem e da poluição, que armazenam expressivos volumes de água. Podem ser citados, como exemplos, as Bacias Sedimentares do Parnaíba, Recôncavo-Tucano-Jatobá, Potiguar, Araripe, Sergipe-Alagoas, Pernambuco-Paraíba, além do Grupo Barreiras e outras ocorrências sedimentares de menor expressão.

Algumas capitais nordestinas como Natal, São Luís, Teresina, Recife, Aracaju e Maceió são abastecidas parcialmente por poços tubulares, que exploram aquíferos de natureza sedimentar (porosos); na zona rural, muitas vezes são a única fonte que subsiste aos rigores da seca. Em contrapartida, cerca de mais de $55,0 \%$ das rochas que formam o arcabouço geológico da Região Nordeste são de natureza cristalina (granitos, gnaisses, quartzitos, migmatitos). Nelas, a circulação das águas subterrâneas só é possível através das fraturas, o que resulta em reservatórios pouco promissores, com reservas limitadas e, sobretudo, com águas geralmente salinas, conforme demonstram os mapas apresentados.

O Mapa hidrogeológico da Região Nordeste ${ }^{4}$ (Mapa 7) tem como base as características hidrogeológicas das diferentes rochas que ocorrem nessa região e representa um conjunto de unidades geológicas com características hidrogeológicas similares.

\footnotetext{
4 Os dados de vazão foram obtidos de um cadastro de 54864 poços tubulares oriundos do Sistema de Informações de Águas Subterrâneas - SIAGAS desenvolvido pelo Serviço Geológico do Brasil - CPRM; da Superintendência do Desenvolvimento do Nordeste - Sudene; do Departamento Nacional de Obras Contra as Secas - DNocs; da Companhia de Engenharia Rural da Bahia CERB; da Companhia de Desenvolvimento do Piauí - ComDepl; da Companhia de Desenvolvimento de Recursos Minerais da Paraíba - CDRM; da Companhia de Desenvolvimento Econômico de Sergipe - CodısE; da Fundação Cearense de Meteorologia e Recursos Hídricos - Funceme; da Companhia de Saneamento Ambiental do Maranhão - CaemA; da Companhia de Águas e Esgotos do Rio Grande do Norte - Caern; Companhia de Água e Esgotos da Paraíba - Cagepa; e da Companhia de Saneamento de Alagoas - CaSAl.
} 


\section{Mapa 7 - Mapa hidrogeológico da Região Nordeste}

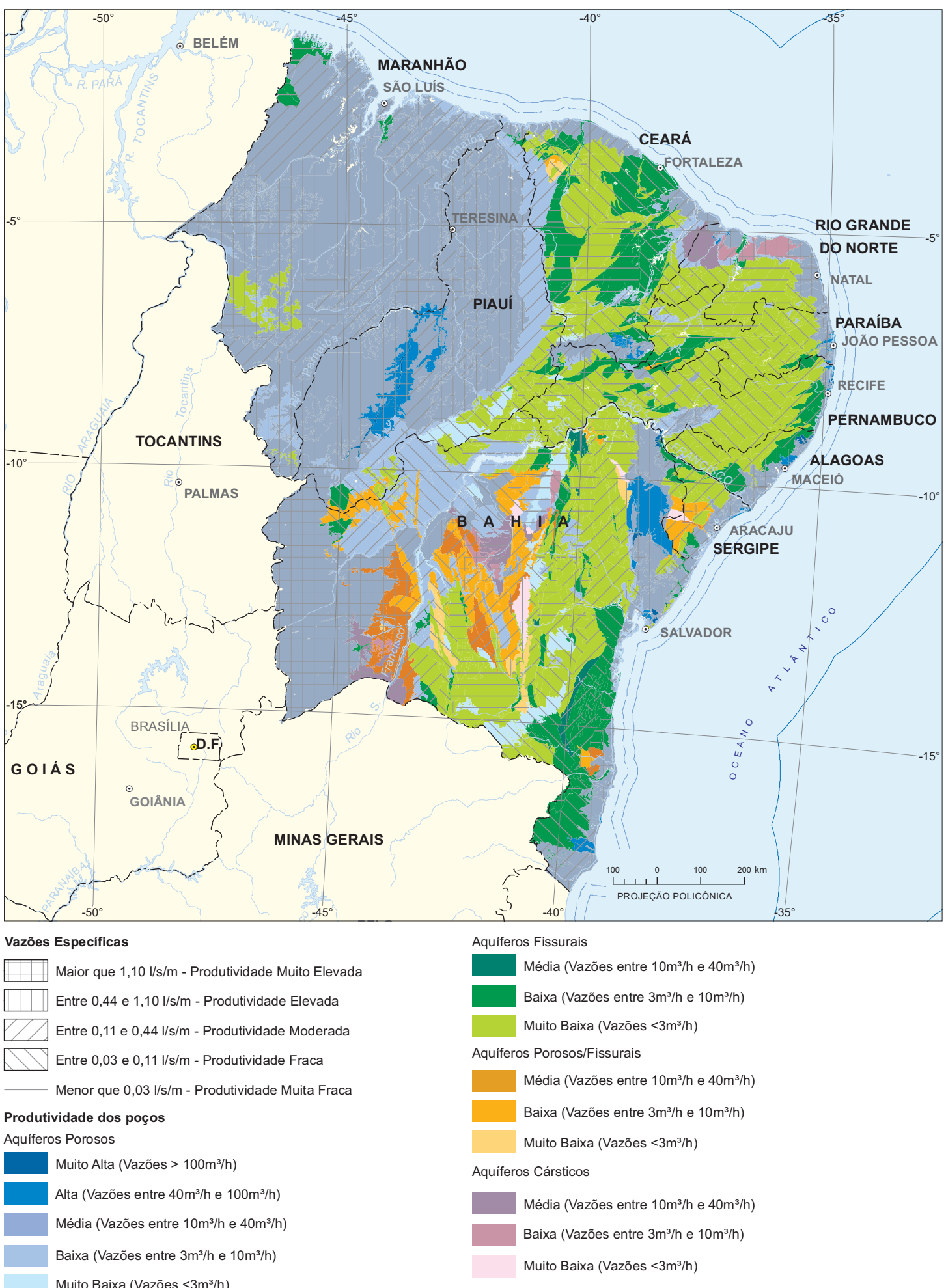

Fonte: Mapa hidrogeológico da região nordeste do Brasil. IBGE, 2013. Disponível em: <ftp://geoftp.ibge.gov.br/informacoes_ambientais/geologia/levantamento_hidrogeologico_e_hidroquimico/mapas/regionais/nordeste_hidrogeologico.pdf >. Acesso em jun. 2016. 
A vazão pode ser definida como a quantidade de litros d'água (ou de metros cúbicos) que pode ser extraída, por unidade de hora, de um determinado ponto de captação subterrânea (poço tubular). A média das vazões calculadas para um sistema aquífero serve como referência para estabelecer-se o potencial de exploração dos poços daquela unidade. Por exemplo, poços com vazões inferiores a $3 \mathrm{~m}^{3} / \mathrm{h}$ (considerada muito baixa) são bastante comuns entre os aquíferos fissurais e permitem atender apenas a pequenas demandas (fazendas e pequenos aglomerados), enquanto que poços com vazões superiores a $100 \mathrm{~m}^{3} / \mathrm{h}$ (encontrados com certa frequência em regiões onde ocorrem os aquíferos porosos) podem abastecer núcleos populacionais relativamente maiores. Enquanto que a vazão mede apenas o potencial médio dos pontos de captação (poço), a vazão específica vai um pouco mais além, permitindo uma avaliação regional e se refere, portanto, à produtividade do conjunto da unidade hidrogeológica.

A vazão específica é definida pela relação entre a vazão e o rebaixamento (que é a diferença que ocorre no nível da água do aquífero após o bombeamento), ou seja, para um mesmo valor de vazão, quanto menor for a variação sofrida pelo impacto do bombeamento, maior será a vazão e, portanto, maior a produtividade do aquífero. Isto significa dizer, que um aquífero cuja vazão específica é elevada (maior que 1,10 litro/segundo/metro) não sofre grandes perdas de volume durante o bombeamento, como é o caso, por exemplo, das grandes bacias sedimentares que ocorrem no Maranhão-Piauí (Bacia do Parnaíba), Bahia-Pernambuco (Bacia Recôncavo-Tucano-Jatobá) e Rio Grande do Norte (Bacia Potiguar), consideradas as maiores reservas de águas subterrâneas da Região Nordeste.

Os aquíferos porosos (geralmente desenvolvidos em rochas denominadas arenitos) detêm as maiores vazões da Região Nordeste. Isto se deve não só à estrutura desses depósitos - semelhantes a uma esponja -, como também devido às suas grandes extensões territoriais e ao grande espaço que dispõem para armazenar suas reservas em água subterrânea (em alguns casos, com mais de 3000 metros de espessura). Já os aquíferos fissurais apresentam espaços bastante limitados para armazenar suas reservas, haja vista que têm natureza impermeável (a exemplo dos granitos e gnaisses) e as fraturas, que são feições localizadas, constituem o único caminho para que as águas infiltradas a partir das chuvas (escassas e concentradas em poucos meses no ano) atinjam o manancial, de modo que a maior parte das precipitações pluviométricas tem como destino o escoamento superficial.

A deficiência na realimentação das reservas faz com que as vazões dos poços perfurados nos aquíferos fissurais da região sejam, em geral, reduzidas (menor que $3 \mathrm{~m}^{3} / \mathrm{h}$ ) e as águas geralmente salinizadas (salgadas e salobras), sendo bastante expressivo o número de poços secos e abandonados. Embora ocupando quase $60 \%$ do espaço nordestino, os aquíferos fissurais têm exploração limitada para fins de abastecimento humano, em função de tais características, e quase sempre utilizados para abastecimento animal.

Os aquíferos cársticos são pouco frequentes (Bahia e Rio Grande do Norte) e, em certa medida, se parecem com os aquíferos fissurais, diferenciando destes na forma dos condutos aquíferos, já que nestes as fraturas encontram-se ampliadas pela dissolução cárstica, dando origem a cavernas, depressões (dolinas) e rios subterrâneos. São importantes sobretudo na irrigação, com destaque para as regiões de Irecê, na Bahia e Mossoró, no Rio Grande do Norte, principalmente devido ao fato de que são escassos os recursos superficiais nessas áreas. 
Os aquíferos porosos-fissurais possuem, simultaneamente, porosidades de interstícios (poros) e de fraturas, sendo as melhores vazões $\left(10 \mathrm{~m}^{3} / \mathrm{h}\right.$ a $\left.40 \mathrm{~m}^{3} / \mathrm{h}\right)$ restritas a áreas submetidas a intenso fraturamento e situadas em regiões com bons índices pluviométricos e de relevo pouco acidentado.

O Mapa hidrogeológico da Região Nordeste e a descrição de suas diferentes nuances, representativos dos diversos potenciais de produção hídrica existentes nessa região, deixam evidenciado o complexo quadro de condicionantes naturais relativos ao acesso aos recursos hídricos superficiais e subterrâneos que são, sem dúvida, fundamentais para garantir à população da Região a disponibilidade e o acesso à água. Esta garantia se constitui, dentre outras metas, em um dos objetivos de desenvolvimento sustentável (Mapa 7).

\section{Vulnerabilidade social e ambiental}

Cientificamente, "está bem estabelecido que os serviços ecossistêmicos prestados por águas interiores são vitais para o bem-estar humano e redução da pobreza" (DUGAN, 1990; REVENGA; KURA, 2003; FINLAYSON et al., 1992; FINLAYSON; MOSER, 1991; WHIGHAM et al., 1993; MITSCH, 1994; MCCOMB; DAVIS, 1998; LUNDQVIST; GLEICK, 2000 apud ECOSYSTEMS..., 2005, p. 575, tradução nossa). Os benefícios desses serviços para o bem-estar humano e, portanto, a degradação dos mesmos afetam diretamente e, em particular, a disponibilidade de água doce, de alimentos, de ciclagem de nutrientes, o tratamento de resíduos e desintoxicação, a regulação das ameaças naturais (enchentes, secas, etc.) e vários serviços culturais e religiosos (ECOSYSTEMS..., 2005).

Os impactos sobre o bem-estar humano quando da degradação dos serviços de suporte e regulação de águas interiores, muitas vezes não são reconhecidos tão facilmente quanto aqueles serviços de provisionamento de água (vide o racionamento causado pela diminuição da quantidade de água disponível para abastecimento em diversos centros urbanos no Brasil). Mas ele pode ser muito significativo quando, por exemplo, reduz-se a capacidade de uma zona úmida de filtrar a água ou desintoxicar os resíduos, provocando consequências significativas para a saúde humana.

Na perspectiva da vulnerabilidade social, Freire (2011) afirma que, embora complexa e por vezes polêmica, esta questão implica conhecer e analisar o espaço geográfico em suas mais variadas dimensões, escalas e percepções. Esse mesmo autor, em 2008, ao realizar um trabalho de identificação das áreas da bacia hidrográfica do São Francisco com maior grau de vulnerabilidade social, construiu um indicador considerando quatro características fundamentais de municípios cujos domicílios encontram-se em situação de precariedade: em decorrência do baixo rendimento, da presença de crianças, do responsável com baixa escolaridade e da insuficiência dos serviços de saneamento básico (FREIRE et. al., 2008).

Sobre o acesso aos serviços de saneamento básico (CENSO DEMOGRÁFICO 2010, 2011) e condições de vida, ligadas direta ou indiretamente aos recursos hídricos, a construção de indicadores relacionados é bastante útil para contextualização das regiões hidrográficas brasileiras no que se refere ao atendimento de aspectos básicos. Em tese, tais indicadores refletem a correta apropriação dos recursos hídricos pela população para a satisfação das 
condições de vida consideradas no contexto do desenvolvimento sustentável. As condições de saneamento representam um dos requisitos básicos para a qualidade de vida da população. O acesso simultâneo à água potável, ao esgotamento sanitário e à coleta de lixo é o requisito mínimo para um ambiente saudável.

Tais situações repercutem diretamente sobre a saúde da população, em particular das crianças e idosos, ao impedirem que as condições de qualidade da água e de exposição ao lixo se tornem sérios vetores de doenças. Isso demonstra, novamente, a íntima relação entre o bem-estar da população com a saúde dos ecossistemas aquáticos e uso racional dos recursos hídricos. A Avaliação Ecossistêmica do Milênio afirma, com alto grau de certeza científica, que

\begin{abstract}
A manutenção de um fluxo adequado de água de boa qualidade é necessário para manter a saúde dos sistemas de águas interiores, bem como de estuários e deltas. O inverso também é verdadeiro: os sistemas de águas interiores saudáveis geram e mantém os fluxos adequados de água de boa qualidade. À medida que os serviços de apoio de águas interiores são o resultado de interações entre os componentes ecológicos dentro do sistema e as da bacia hidrográfica, o bemestar humano está inexoravelmente ligados à manutenção do caráter ecológico dos sistemas de águas interiores (ECOSYSTEMS..., 2005, p. 575, tradução nossa).
\end{abstract}

A vulnerabilidade social decorre, assim, de fenômenos diversos, com causas e consequências distintas, a partir de uma visão mais complexa das condições de vida e dos riscos sociais que atingem os vários segmentos populacionais, bem como das possibilidades de sua superação ou minimização.

"Como o bem-estar humano é fortemente afetado pela medida em que as pessoas são capazes de satisfazer as suas necessidades mais básicas (água, comida, abrigo e saúde) de uma maneira segura, o uso sustentável das águas, para garantir bem-estar humano, é vital" (ECOSYSTEMS..., 2005, p. 575, tradução nossa). Ou seja, para se abordar o tema da qualidade de vida, faz-se necessário incorporar à análise os outros elementos que permitem a um indivíduo viver com dignidade e segurança, dentre eles, os elementos do capital natural, conforme relatado nesse capítulo.

\title{
Referências
}

AGÊNCIA NACIONAL DE ÁGUAS (Brasil). Programa de ações estratégicas para o gerenciamento integrado do Pantanal e bacia do Alto Paraguai: relatório final. Brasília, DF: ANA, 2004.315 p. Acima do título: Implementação de práticas de gerenciamento integrado de bacia hidrográfica para o Pantanal e a Bacia do Alto Paraguai. Disponível em: <file:///C:/ Users/1367242/Downloads/20091202140622_ALTO_PARAG_REL_FINAL.pdf $>$. Acesso em: maio 2016.

ALHO, C. J. R. et. al. Conservação da biodiversidade da bacia do Alto Paraguai. Campo Grande, MS: Ed.Uniderp, 2003. 466 p.

ALHO, C. J. R.; LACHER JÚNIOR, T. E.; GONÇALVES, H. C. Environmental degradation in the Pantanal ecosystem: in Brazil, the world's largest wetland is being threatened by human 
activities. BioScience, Oxford: Oxford University Press; Washington, DC: American Institute of Biological Sciences, v. 38, n. 3, p. 164 -171, mar. 1988. Disponível em: <http://www.jstor. org/stable/i256205>. Acesso em: maio 2016.

ANDRADE-LIMA, D. de. Present-day forest refuges in northeastern Brazil. In: INTERNATIONAL SYMPOSIUM FOR THE ASSOCIATION FOR TROPICAL BIOLOGY, 5., 1979, Caracas. Biological diversification in the tropics: proceedings.... Nova York: Columbia University Press, 1982. p. 245-251.

ATLAS nacional do Brasil Milton Santos. Rio de Janeiro: IBGE, 2010. Disponível em: <http:// biblioteca.ibge.gov.br/index.php/biblioteca-catalogo?view=detalhes\&id=247603>. Acesso em jun. 2016.

BARELLA, W. et.al. As relações entre as matas ciliares, os rios e os peixes. In: RODRIGUES, R. R.; LEITÃO FILHO, H. F. (Ed.). Matas ciliares: conservação e recuperação. São Paulo: Edusp; Fundação de Amparo à Pesquisa do Estado de São Paulo - Fapesp, 2001. p. 187-207.

BIOMAS. Brasília, DF: Ministério do Meio Ambiente, [2015]. Disponível em: <http://www. mma.gov.br/biomas> Acesso em: maio 2016.

BRASIL. Lei n. 9.433, de 8 de janeiro de 1997. Institui a Política Nacional de Recursos Hídricos, cria o Sistema Nacional de Gerenciamento de Recursos Hídricos, regulamenta o inciso XIX do art. 21 da Constituição Federal, e altera o art. $1^{\circ}$ da Lei n. 8.001, de 13 de março de 1990, que modificou a Lei n. 7.990, de 28 de dezembro de 1989. Diário Oficial [da] República Federativa do Brasil, Brasília, DF, ano 135, n. 6, 09 jan. 1997. Seção 1, p. 470-474. Disponível em: <http://www.presidencia.gov.br/legislacao >. Acesso em: maio 2016.

CENSO DEMOGRÁFICO 2010. Características da população e dos domicílios: resultados do universo. Rio de Janeiro: IBGE, 2011. Disponível em: <http://www.ibge.gov.br/home/ estatistica/populacao/censo2010/caracteristicas_da_populacao/default_caracteristicas_da_ populacao.shtm>. Acesso em: maio 2016.

COIMBRA FILHO, A. F.; CÂMARA, I. de G. Os limites originais do bioma Mata Atlântica na região nordeste do Brasil. Rio de Janeiro: Fundação Brasileira para Conservação da Natureza, 1996. 86 p.

CONJUNTURA dos recursos hídricos no Brasil 2013. Brasília, DF: Agência Nacional de Águas - ANA, 2013. 432 p. Disponível em: <http://arquivos.ana.gov.br/institucional/spr/ conjuntura/webSite_relatorioConjuntura/projeto/index.html>. Acesso em: maio 2016.

CONSELHO NACIONAL DE RECURSOS HÍDRICOS (Brasil). Resolução n. 32, de 15 de outubro de 2003. Institui a Divisão Hidrográfica Nacional. Brasília, DF: CNRH, 2003. Disponível em: <http:// www.cnrh.gov.br/index.php?option=com_content\&view=article\&id=14>.Acessoem: maio2016. ECOSYSTEMS and human well-being: a framework for assessment. Washington, DC: Island Press, 2003. 245 p. Relatório apresentado pelo Grupo de Trabalho Millennium Ecosystem Assessment. Disponível em: <http://pdf.wri.org/ecosystems_human_wellbeing.pdf>. Acesso em: maio 2016.

ECOSYSTEMS and human well-being: current state and trends: findings of the Condition and Trends Working Group of the Millennium Ecosystem Assessment. Washington, DC: Island 
Press, 2005. 901 p. (Millennium ecosystem assessment series, v. 1). Disponível em: <http:// millenniumassessment.org/en/Condition.html>. Acesso em: maio 2016.

ESTIMATIVAS da população residente nos municípios brasileiros com data de referência em 1o de julho de 2013. Rio de Janeiro: IBGE, 2013. Disponível em: <ftp://ftp.ibge.gov.br/ Estimativas_de_Populacao>. Acesso em: maio 2016.

FREIRE, N. C. F. Diagnóstico jurídico-institucional. In: DIAGNÓSTICO do macrozoneamento ecológico-econômico da bacia hidrográfica do rio São Francisco. Brasília, DF: Ministério do Meio Ambiente, 2011. p. 415-445. Disponível em: <http://www.mma.gov.br/gestao-territorial/ zoneamento-territorial/macrozee-da-bacia-do-s\%C3\%A3o-francisco/item/10439>. Acesso em: maio 2016.

FREIRE, N. C. F. et. al. Tipologia da vulnerabilidade social na bacia de São Francisco. Trabalho apresentado no II Simpósio Brasileiro de Ciências Geodésicas e Tecnologias da Geoinformação, realizado em Recife, 2008. Disponível em: <https://www.ufpe.br/cgtg/ SIMGEOII_CD/Organizado/cart_sig/157.pdf>. Acesso em: maio 2016.

GALDINO, S.; VIEIRA, L. M.; SORIANO, B. M. A. Erosão na bacia do Alto Taquari. Corumbá: Empresa Brasileira de Pesquisa Agropecuária - Embrapa, 2003. 46 p. (Documentos, n. 52) Disponível em: <http://www.cpap.embrapa.br/publicacoes/online/DOC52.pdf>. Acesso em: maio 2016.

GALVÃO, A. L. C. de O.; GALVÃO, W. S. As relações espaciais entre os dados de localização de cavernas e as ottobacias: bacias hidrográfica geocodificada do Brasil. Revista Brasileira de Espeleologia, Brasília, DF: Centro Nacional de Pesquisa e Conservação de Cavernas, v. 2, n. 2, p. 38-56, 2012. Disponível em: <http://www.icmbio.gov.br/revistaeletronica/index. php/RBEsp/article/view/315/pdf>. Acesso em: maio 2016.

ÍNDICE paulista de vulnerabilidade social. São Paulo: Fundação Sistema Estadual de Análise de Dados - Seade, [2015]. Disponível em: <http://produtos.seade.gov.br/projetos/ipvs/>. Acesso em: maio 2016.

INTERNATIONAL recommendations for water statistics. New York: United Nations, Statistics Division, 2012. 197 p. (Statistical papers, Series M, n. 91). Disponível em: <http://unstats. un.org/unsd/envaccounting/pubs.asp>. Acesso em: maio 2016.

JUNK, W. J. et. al. Brazilian wetlands: their definition, delineation, and classification for research, sustainable management, and protection. Aquatic Conservation: marine and freshwater ecosystems, Chichester, GB: John Wiley \& Sons, v. 24, n. 1, p. 5-22, 2014. Disponível em: <http:// onlinelibrary.wiley.com/journal/10.1002/(ISSN)1099-0755/issues>. Aceso em: maio 2016.

LEVANTAMENTO da cobertura vegetal nativa do bioma mata atlântica: relatório final. Rio de Janeiro: Instituto de Estudos Socioambientais do Sul da Bahia - IESB, 2007. 84 p. Acima do título: Projeto de conservação e utilização sustentável da diversidade biológica brasileira - Probio. Disponível em: <http://mapas.mma.gov.br/geodados/brasil/vegetacao/ vegetacao2002/mata_atlantica/documentos/relatorio_final.pdf>. Acesso em: maio 2016.

MAPA de biomas do Brasil: primeira aproximação. Rio de Janeiro: IBGE, 2004a. 1 mapa. Escala 1:5 000 000. Projeção policônica. 
MAPA de biomas e de vegetação. Rio de Janeiro: IBGE, 2004b. Disponível em: <http://www. ibge.gov.br/home/presidencia/noticias/21052004biomashtml.shtm>. Acesso em: maio 2016.

MAPA de vegetação do Brasil. Rio de Janeiro: IBGE, 2004c. 1 mapa, color. Escala 1:5000 000. Projeção policônica. Disponível em: <ftp://geoftp.ibge.gov.br/informacoes_ambientais/ vegetacao/mapas/brasil/vegetacao.pdf>. Acesso em jun. 2016.

MAPA hidrogeológico da região nordeste do Brasil. IBGE, 2013. 1 mapa, color. Escala 1:2 500 000. Projeção policônica. Disponível em: <ftp://geoftp.ibge.gov.br/informacoes_ ambientais/geologia/levantamento_hidrogeologico_e_hidroquimico/mapas/regionais/ nordeste_hidrogeologico.pdf>. Acesso em: jun. 2016.

MONITORAMENTO do desmatamento nos biomas brasileiros por satélite: monitoramento do bioma caatinga 2008-2009. Brasília, DF: Ministério do Meio Ambiente: Instituto Brasileiro do Meio Ambiente e dos Recursos Naturais Renováveis - Ibama, 2011a. 46 p. Disponível em: <http://www.mma.gov.br/estruturas/sbf_chm_rbbio/_arquivos/relatorio_ tecnico_caatinga_2008_2009_72.pdf>. Acesso em: maio 2016.

MONITORAMENTO do desmatamento nos biomas brasileiros por satélite: monitoramento do bioma cerrado 2009-2010. Brasília, DF: Ministério do Meio Ambiente: Instituto Brasileiro do Meio Ambiente e dos Recursos Naturais Renováveis - Ibama, 2011b. [64] p. Disponível em: <http://www.mma.gov.br/estruturas/sbf_chm_rbbio/_arquivos/relatoriofinal_ cerrado_2010_final_72_1.pdf>. Acesso em: maio 2016.

MONITORAMENTO do desmatamento nos biomas brasileiros por satélite: monitoramento do bioma mata atlântica 2008-2009. Brasília, DF: Ministério do Meio Ambiente: Instituto Brasileiro do Meio Ambiente e dos Recursos Naturais Renováveis - Ibama, 2012. [100 p.]. Disponível em: <http://www.mma.gov.br/estruturas/sbf_chm_rbbio/_arquivos/relatorio_ tcnico_mata_atlantica_2008_2009_72.pdf>. Acesso em: maio 2016.

MONITORAMENTO do desmatamento nos biomas brasileiros por satélite: monitoramento do bioma pampa 2008-2009. Brasília, DF: Ministério do Meio Ambiente: Instituto Brasileiro do Meio Ambiente e dos Recursos Naturais Renováveis - Ibama, 2011c. [34] p. Disponível em: <http://www.mma.gov.br/estruturas/sbf_chm_rbbio/_arquivos/relatrio_tcnico_ monitoramento_pampa_2008_2009_72.pdf>. Acesso em: maio 2016.

MONITORAMENTO do desmatamento nos biomas brasileiros por satélite: monitoramento do bioma pantanal 2008-2009. Brasília, DF: Ministério do Meio Ambiente: Instituto Brasileiro do Meio Ambiente e dos Recursos Naturais Renováveis - Ibama, 2011d. 30 p. Disponível em: <http://www.mma.gov.br/estruturas/sbf_chm_rbbio/_arquivos/relatrio_ tcnico_monitoramento_pantanal_2008_2009_72.pdf>. Acesso em: maio 2016.

PRADO, D. E. As caatingas da América do Sul. In: LEAL, I. R.; TABARELLI, M.; SILVA, J. M. C. (Ed.). Ecologia e conservação da Caatinga. Recife: Universidade Federal de Pernambuco UFPE, 2003. p. 3-73. Disponível em: <http://www.mma.gov.br/estruturas/203/_arquivos/5_ livro_ecologia_e_conservao_da_caatinga_203.pdf> Acesso em: maio 2016. 
SANTOS, J. R. Avanços das pesquisas e aplicações de sensoriamento remoto no monitoramento da paisagem: contribuições aos estudos do Pantanal. In: SIMPÓSIO DE GEOTECNOLOGIAS NO PANTANAL, 1., 2006, Campo Grande. Anais... Campo Grande: Empresa Brasileira de Pesquisa Agropecuária - Embrapa; Embrapa Informática Agropecuária; Instituto Nacional de Pesquisas Espaciais - INPE, 2006, p. 675-683. Disponível em: <https:// www.geopantanal.cnptia.embrapa.br/2010/publicacoes.html>. Acesso em: maio 2016.

SEN, A. Capability and well-being. In: NUSSBAUM, M.; SEN, A. (Ed.). The quality of life. Oxford: Clarendon Press; New York: Oxford University Press, 1993. p. 30-553.

SYSTEM of environmental-economic accounting 2012: central framework. New York: United Nations, 2014. 346 p. Preparado sob os auspícios da Organização das Nações Unidas ONU, Comissão das Comunidades Européias - Eurostat, Organização das Nações Unidas para a Alimentação e a Agricultura - FAO, Fundo Monetário Internacional - IMF, Organização para a Cooperação e o Desenvolvimento Econômico - OCDE, e Banco Mundial. Disponível em: <http://unstats.un.org/unsd/envaccounting/pubs.asp>. Acesso em: maio 2016.

SYSTEM of environmental-economic accounting for water - SEEA-water. New York: United Nations, Department of Economic and Social Affairs, 2012.197 p. Preparado em colaboração com o subgrupo de contas de água, do grupo de Londres sobre contas ambientais. Disponível em <http://unstats.un.org/unsd/envaccounting/pubs.asp>. Acesso em: maio 2016. 
